\title{
Corporate Social Responsibility in Buyer- Supplier Relationships: Is it Beneficial for Top- Tier Suppliers to Market their Capability to Ensure a Responsible Supply Chain?
}

\author{
Thomas Leppelt, Institute for Supply Chain Management, Friedrich-Alexander-University Erlangen-Nuremberg, Germany, \\ E-Mail: thomas.leppelt@web.de \\ Kai Foerstl, Institute for Supply Chain Management, EBS Business School, Germany, E-Mail: kai.foerstl@ebs.edu \\ Evi Hartmann, Institute for Supply Chain Management, Friedrich-Alexander-University Erlangen-Nuremberg, Germany, \\ E-Mail: evi.hartmann@wiso.uni-erlangen.de
}

\begin{abstract}
This study assesses how top-tier suppliers market their capabilities to ensure a responsible upstream supply chain to their downstream buyers, and how the marketing of corporate social responsibility (CSR)related supply management practices affects the reputation of top-tier suppliers in business-to-business (B2B) markets. In a cross-functional multiple-case study involving marketing, purchasing, and sustainability executives of five supplier organizations in Central Europe, we explored four distinct approaches for marketing superior CSR management abilities in $\mathrm{B} 2 \mathrm{~B}$ markets that potentially foster long-term comparative advantages: (1) Fact-based communication of measurable CSR capabilities, (2) targeting of indirect customers and influencers, (3) marketing through education, and (4) marketing of CSR as a service. Moreover, our inductive results provide evidence that the effective marketing of CSR capabilities enhances a supplier's reputation only if it sends consistent signals to the market. Therefore, a close integration of marketing and purchasing is crucial for achieving signaling consistency. Building on an established framework of purchasing-marketing integration in the particular context of CSR we developed a crossfunctional theory on the link between marketing, supply chain alignment and reputation, which is expressed in four sets of testable research propositions.
\end{abstract}

JEL-classification: M14, M21, M39, L6o

Keywords: business markets, case study research, corporate social responsibility, cross-functional research, marketing, supply chain management, supply management

Manuscript received June 25, 2012, accepted by Sönke Albers (Marketing) April 21, 2013.

\section{$1 \quad$ Introduction}

Corporate social responsibility (CSR) research increasingly focuses on the link between CSR-related business practices and corporate reputation (e.g., Husted and De Jesus Salazar 2006; Janney and Gove 2011; McWilliams, Siegel, and Wright 2006). In this context, scholars argued that social or environmental misconduct is not necessarily detrimental to an organization, as long as the firm does not purposely cause misconduct and promptly rectifies the wrongdoing (Campbell 2007). But what if the wrongdoing occurs not at the globally recognized brand, but at a supplier or a sub-supplier in its supply chain? And what if the brand owner is held accountable for supplier misconduct?

Only recently, companies such as Mattel and the German school-catering firm Sodexo have been held responsible for supplier misconduct in the upstream supply chain outside of their direct hierarchical control. In Mattel's case, millions of toys had to be recalled because independent Chinese vendors manufactured them using lead paint (Lee, Tseng, 
and Hoyt 2008; Tang 2008). In the case of Sodexo, contaminated frozen strawberries from a Chinese sub-supplier caused an E. coli outbreak among nearly 11,000 German pupils. Also in this case Sodexo's vendors and contractors played a crucial role prior to the incident, as the contamination was caused by a Chinese sub-supplier that presumably did not adhere to agreed hygiene standards (FAZ 2012). Both cases of supplier misconduct had a significant negative impact on the companies' reputations and led to declining sales figures. The examples of Mattel and Sodexo reveal the critical role of suppliers in ensuring responsibility along the supply chain. Formerly rather invisible to end-consumers, suppliers are now exposed to constant surveillance by well-informed, sustainability-conscious endconsumers (Auger, Devinney, Louviere, and Burke 2010), non-governmental organizations (NGOs), and other interest groups, and therefore directly influence their buyers' reputation through their behavior. This effect intensifies as, for instance, NGOs increasingly direct their CSR pressure on the supply chains of the firms with the dominant brand name (Amaeshi, Osuji, and Nnodim 2008).

This study focuses on suppliers in a competitive supply chain setting and their business behavior in the context of increasing external CSR pressure. We concentrate on one particular group of suppliers, top-tier suppliers, which are closest to the manufacturer of the final product and which often manage large parts of their buyer's upstream supply chain (Kamath and Liker 1994). Buying firms - which in the context of this research are defined as firms that manufacture and market the final branded product and that have mainly strategic relationships with their top-tier suppliers - cannot devote infinite resources to control the operations within their network of upstream suppliers and sub-suppliers. As a consequence, top-tier suppliers often advance to "CSR gatekeepers" for their buyers, which can prevent them from reputational harm through misconduct at the supply chain level due to their closeness to component and raw-material suppliers (subsuppliers) and their deeper knowledge of the underlying processes (Lee and Klassen 2008; Wolf 2011). Despite their critical role as enablers of a responsible supply chain, top-tier suppliers confront changing business conditions. Due to an increasing number of publically reported cases of social or environmental misconduct and heightened public interest in a company's ethical behavior, buying firms increasingly reevaluate and revisit their existing supplier base against CSR-related measures (Carter and Rogers 2008; Tate, Ellram, and Kirchoff 2010). For top-tier suppliers, this development means both challenges and opportunities. The challenging part is that top-tier suppliers confront new business requirements related to $\mathrm{CSR}$, such as certification and compliance requirements, or proof of CSRrelated business practices even beyond their own corporate boundaries, from both existing buyers and potential new customers. From an opportunity perspective, the buyer-sided revisit of the supplier base may break up existing buyer-supplier structures and generate additional business opportunities for those top-tier suppliers that, all other things being equal, can convince the market of their superior capability to ensure a responsible upstream supply chain. However, top-tier suppliers need to avoid purposefully overstating their own CSR capabilities, a practice often referred to as "greenwashing," which might harm the supplier's trustworthiness. A positive reputation towards CSR in this context can equip top-tier suppliers with a competitive advantage in their respective customer markets (McWilliams, Siegel, and Wright 2006). First, it enhances the probability of winning additional business in the case that potential buyers, who are not yet customers of the supplier, are looking for alternatives with a CSR-ensuring capability. Second, it can help to retain existing business when a buying firm reassesses its existing supplier base with regards to CSR.

However, in order to actually achieve the mentioned benefits, a top-tier supplier would need to fulfill two conditions: First, it must be capable of actually ensuring a responsible upstream supply chain through respective CSR-related business practices in its purchasing operations (as the purchasing function usually manages a company's upstream supply chain). Second, it would need to make existing and potential buyers aware of its supply chain-oriented CSR capabilities through proper marketing and communication of existing capabilities (a task usually performed by the sales and marketing function). As the subject matter of the study affects both purchasing and marketing practices, we investigate the CSRrelated business operations within both functions, as well as their integration. A close integration of purchasing and marketing is critical for ensuring that buyer-induced CSR requirements are reflected in the supplier's upstream supply chain, as well as 
for adequately communicating the supplier's CSRrelated supply chain capabilities to the market (Sheth, Sharma, and Iyer 2009). Even though this study focuses primarily on the integration between purchasing and marketing, the collaboration with other central corporate functions such as CSR or environmental health and safety additionally helps to integrate the supplier perspective with the customer perspective of the top-tier supplier. While the practices for managing CSR in the upstream supply chain have been widely discussed in the extant purchasing and supply management literature (e.g., Pagell and Wu 2009; Paulraj 2011), the questions of (1) how top-tier suppliers use supply chain-oriented CSR management capabilities for marketing purposes and (2) how in particular top-tier suppliers manage the cross-functional integration of the purchasing and the marketing function, remain rather unexplored in extant supply chain management (SCM) and marketing literature. Specifically, to date it is not clear through which practices and concepts top-tier suppliers market their ability to ensure a responsible supply chain and how such efforts affect the top-tier supplier's reputation.

This study aims to answer these questions by exploring distinct concepts through which top-tier suppliers market superior CSR-related SCM capabilities, and the role of the purchasing-marketing integration in these concepts. Given the sparse literature on the subject and the infancy of academic research on CSR along the supply chain (McWilliams, Siegel, and Wright 2006) we opted for an exploratory case study research design based on a multiple-case study of five top-tier suppliers within the European Union. Thereupon, we contribute to the extant CSR literature in several ways: First, we aim to extend existing theory on purchasingmarketing integration and reputation by adapting an established theoretical framework on the crossfunctional integration of marketing and purchasing developed by Sheth, Sharma, and Iyer (2009), which also serves as the conceptual basis for structuring the case study findings, to the particular context of CSR and its link to reputation. Second, we explore distinct concepts for marketing superior CSR-related SCM capabilities in a B2B context. Third, we develop theoretical propositions related to the link between CSR-related business practices and reputation based on the assumptions of signaling theory (Cornelissen, Haslam, and Balmer 2007; Rao 1994).
The remainder of this article is structured as follows: First, we review the relevant literature in the disciplines of general management, SCM, and marketing. Next, we present the conceptual framework for the study, as well as our research method. Third, we explore the top-tier suppliers' concepts for marketing a CSR-oriented SCM capability in a B2B context and inductively derive theoretical propositions on the CSR-reputation link. We conclude with implications, limitations, and areas for further research.

\section{$2 \quad$ Literature review}

\subsection{A cross-functional perspective on corporate social responsibility}

In academia corporate social responsibility (CSR) has developed into an omnipresent topic over the years. A broad body of literature evolved around different aspects of responsible corporate behavior focusing on various corporate functions and academic disciplines such as management, marketing or supply chain management (cf., Closs, Speier, and Meacham 2011; McWilliams and Siegel 2001; Seuring and Mueller 2008). The concept of corporate social responsibility (CSR) is characterized by a broad variety of definitions (McWilliams and Siegel 2001) within and across research disciplines and has morphed significantly. In his research, Carroll (1999) referred to numerous definitions of CSR and the development of the term over time. In the context of this study, we define CSR as "situations where the firm goes beyond compliance and engages in actions that appear to further some social good, beyond the interests of the firm and that which is required by law" (McWilliams and Siegel 2001: 117). By applying this definition to our research context, we refer to a broader conceptualization of CSR that considers a firm's actions rather than its underlying motivation to engage in CSR (Lockett, Moon, and Visser 2006; Janney and Gove 2011).

In addition to the social dimension explicit in the term CSR, the environmental and economic dimensions of corporate activity factor into our notion of CSR. Hence, we follow the concept of the triple bottom line (Elkington 1998), which highlights the need for managers and their firms to focus concurrently on the social, environmental, and economic impact of corporate activity (Henriques and Rich- 
ardson 2004; Van Tulder and Van der Zwart 2006). The triple bottom line appears in the research disciplines of marketing (e.g., Closs, Speier, and Meacham 2011; Hult 2011; Hunt 2011) and SCM (e.g., Carter and Easton 2011; Pagell and Wu 2009; Tate, Ellram, and Kirchoff 2010) as a widely used concept among managers and scholars. Thus, in this paper we use the term CSR synonymously for similar concepts such as sustainability (cf., Hult 2011) or corporate responsibility (cf., Campbell 2007). Moreover, we concur with the notion that companies act responsibly when "they do not knowingly do anything that could harm their stakeholders" and that "they [...] rectify it whenever the harm is discovered and brought to their attention" (Campbell 2007: 951). However, in buyer-supplier relationships the buying firm has incomplete information about its supplier's operations and hence must rely on top-tier supplier capabilities to ensure a responsible upstream supply chain (Spence and Bourlakis 2009).

At the level of the top-tier supplier's own organization, the purchasing function manages the upstream supply chain, a function that scholars have only recently recognized as strategic (e.g., Gadde and Hakanson 2001; Monczka, Trent, and Handfield 2005). With CSR's emergence as a prominent topic in the SCM discipline, a number of scholars have investigated the role of purchasing in the context of a responsible, or sustainable, supply chain (e.g., Carter and Jennings 2004; Hollos, Blome, and Foerstl 2012; Leppelt, Foerstl, Reuter, and Hartmann 2011; Tate, Ellram, and Kirchoff 2010), a major area of future SCM research (Schoenherr, Modi, Benton, Carter, Choi, Larson, Leenders, Mabert, Narasimhan, and Wagner 2012). On the business practice level, Paulraj (2011) pointed to the critical role of a firm's purchasing function, which selects and manages the sub-suppliers. A company's purchasing practices are, therefore, critical to its own as well as its buyer's reputation, as the subsuppliers' environmental and social behavior in turn reflects on their downstream customers.

\subsection{Responsible purchasing practices and their market appreciation}

So why would top-tier suppliers market their ability to ensure a responsible upstream supply chain to their downstream buyers as well as to potential buyers on the business market? Which marketing practices would they apply, given that top-tier sup- pliers act in a B2B context, and how would these CSR-related marketing practices differ from CSRrelated marketing in a business-to-consumer context? To date, marketing literature is still vague in answering these questions, as a significant portion of CSR-related marketing literature refers to consumer marketing rather than to $\mathrm{B} 2 \mathrm{~B}$, business, or industrial marketing (e.g., Carrington, Neville, and Whitwell 2010; Luchs, Naylor, Irwin, and Raghunathan 2010). In a B2B context, authors such as Mudambi (2002) or Balmer and Greyser (2006) argued that firms in business markets usually encounter professional buyers that emphasize tangible attributes such as a supplier's financial strength, technical expertise, and production processes, rather than intangible attributes such as image, brand identification, or emotional satisfaction. In this context CSR is regarded as an intangible attribute, though it contributes to a company's credibility, and may serve as an enabler of trustful business relationships.

This study aims at exploring distinct concepts for marketing CSR-related SCM capabilities in a B2B context, as research is still ambiguous on whether supply chain-oriented CSR capabilities can be considered an order winner (Hill 1985) or an order qualifier - that is, a necessary condition to compete in the business market. Scholars of industrial marketing argued that attributes such as a positive CSR perception or ethical behavior are regarded as necessary prerequisites for potential B2B business partners (e.g., Mudambi 2002). In this context, the marketing of supply chain-oriented CSR management capabilities would be nothing more than making existing and potential buyers aware of the toptier supplier's compliance with particular business requirements. On the other hand, some authors in the management discipline highlighted the strategic relevance of sending positive and consistent CSR signals to the market as a means for differentiation (e.g., Hart 1995; McWilliams, Siegel, and Wright 2006). Yet how companies seek to generate a positive reputation based on their supply chain-oriented CSR practices remains unexplored.

\subsection{Marketing of supply chain-oriented CSR capabilities and firm reputation}

Given that a top-tier supplier deploys superior CSRrelated SCM capabilities that target both suppliers and buyers, how would such practices affect a supplier's reputation? Overall, there is still "a limited 
understanding about the consequences of a buying firm's perception of a supplier's reputation in an SCM context" (Wagner, Coley, and Lindemann 2011: 2). In the context of CSR, some researchers noted that CSR initiatives positively affect a firm's corporate identity and that the assurance of a responsible upstream supply chain positively impacts its reputation as a reliable business partner (Brickson 2007; Cornelissen, Haslam, and Balmer 2007). Reputation itself is considered an intangible asset and is defined as the buyer's perception of the supplier in terms of fairness, honesty, and concern about the buying firm (Ganesan 1994; Wagner, Coley, and Lindemann 2011). As an intangible asset, reputation can be a source of competitive advantage (Hansen, Samuelson, and Silseth 2008), resulting in reduced uncertainty in buyer-supplier relationships (Rindova, Williamson, Petkova, and Sever 2005) and leading to superior financial performance (Eberl and Schwaiger 2005).

In order to explain the effects of a firm's actions and business practices on its reputation, management and marketing scholars only recently applied signaling theory (e.g., Ndofor and Levitas 2004; Connelly, Ketchen, and Slater 2011), and in particular used its established link to the concept of reputation. Signaling theory states that reputation emerges from the accumulation of positive and negative signals, with positive signals enhancing the firm's reputation and negative signals harming it (Rao 1994). Consistent signals create a stable corporate identity, which is positively recognized by customers and therefore enhances reputation (Cornelissen, Haslam, and Balmer 2007). Extended to the context of CSR in supplier-buyer relationships, reputation also includes the buyer's perception of the supplier's ethical behavior (Mudambi 2002). Janney and Gove (2011) only recently used signaling theory to link CSR-related practices with reputation. They argued that a positive reputation for CSR is critical for a positive link between CSR and performance, and that an enhanced overall reputation for CSR can buffer firms from scandal revelations.

However, firms might overstate their own capabilities if they appear more committed to CSR than they actually are (Harrison and Freeman 1999). To shield themselves from a greenwashing accusation, firms apply tangible mechanisms such as certifications of or investments in responsible purchasing practices to signal controllable CSR credentials to their corporate clients (Connelly, Ketchen, and Slater 2011).
From the receiver's perspective, the effectiveness of signaling efforts also depends on the importance of CSR to buyers or investors, as these stakeholders need to be interested in CSR in order to recognize related signals (Jones, Clarke-Hill, Comfort, and Hillier 2008; Schueth 2003). Within our study, signaling theory serves one particular purpose: During the inductive analysis, it serves as the theoretical link between the buyer- and supplier-oriented business practices - which either send positive signals or aim to avoid negative signals - and the effect of these practices on corporate reputation. Hence, we use signaling theory as a proxy for predicting the reputational effects of CSR-oriented supply chain practices.

\section{Conceptual framework for integrating purchasing and marketing}

In $\mathrm{B} 2 \mathrm{~B}$ research, scholars noted that the close integration of marketing and purchasing may contribute to firm performance in network-based competition such as a competitive supply chain setting (Williams, Giunipero, and Henthorne 1994). A recent empirical study on marketing-purchasing integration in B2B markets concluded that a close collaboration between both functions positively affects business performance (Smirnova, Henneberg, Ashnai, Naudé, and Mouzas 2011). Purchasingmarketing integration can, therefore, be conceptualized as a part of a firm's market-sensing capabilities (Day 1994; Foley and Fahy 2004), such as its "ability to identify potential opportunities and align the firm's activities with capabilities and resources of upstream (supplier) and downstream (customer) partners in the market" (Smirnova, Henneberg, Ashnai, Naudé, and Mouzas 2011: 56). Nevertheless, research that combines the purchasing and the marketing perspective against the background of corporate social responsibility (CSR) has been sparse. Scholars have therefore only recently called for more CSR research that combines marketing with SCM (e.g., Carter and Easton 2011; Closs, Speier, and Meacham 2011).

In order to develop theory on the integration of purchasing and marketing practices in the context of CSR, as well as on the effects of these practices on reputation, the framework of Sheth, Sharma, and Iyer (2009) is extended and modified to our research scope. The original framework is based on 
Figure 1: Theoretical framework for the cross-functional investigation of an industrial firm's CSR-related purchasing and marketing practices (modified from Sheth, Sharma, and Iyer 2009)

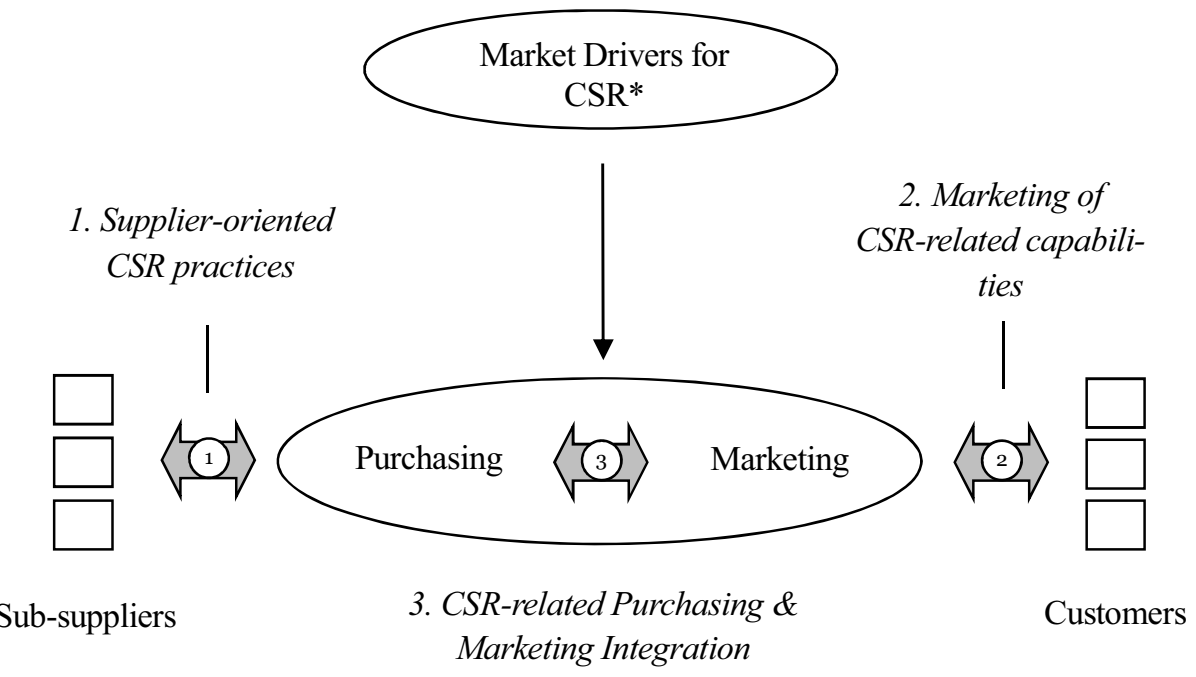

* The most prominent market drivers for CSR among others are globalization and cultural differences, liberalization of markets, de-
mand for sustainability from multiple stakeholder groups such as customers, shareholders, or governments as well as non-
governmental organizations.

the notion that suppliers benefit if their upstream purchasing strategies align with customer demands (Aitken, Childerhouse, and Towill 2003; Childerhouse, Aitken, and Towill 2002), and that closer buyer-supplier relationships requires a closer integration of the two functions managing the external interface (suppliers and customers) with the internal value chain (see Appendix IV).

On the bottom-left side of the framework, Supplieroriented CSR practices (No. 1) represent CSRrelated business practices in the areas of supplier identification, supplier collaboration, and supplier evaluation (Paulraj 2011), such as codes of conduct, environmental or social auditing processes, or CSRrelated supplier risk assessments. In addition to preventing social or environmental misconduct, supplier-oriented CSR initiatives also support the early detection and elimination of CSR-related incidents. Bottom-right in the framework, the Marketing of CSR-related capabilities (No. 2) accumulates practices in the areas of market sensing, positioning, communication, and branding (Day 1994; Foley and Fahy 2004; Srivastava, Shervani, and Fahey 1999), which are used to sense the buyers' individual needs and requirements related to their suppliers' CSR capabilities, and to adequately promote the top-tier suppliers' existing capabilities to existing buyers and the business market. Finally, the dimension CSR- related Purchasing \& Marketing Integration (No. 3 ) in the center of the framework incorporates practices that enable suppliers to cross-functionally align their CSR-related marketing and purchasing activities in order to present a consistent external picture with regards to CSR. Through the course of the study, the adapted model from Sheth, Sharma, and Iyer (2009) will serve as the conceptual basis for analyzing and interpreting our empirical results.

\section{Research method}

In our research we apply a multiple-case study approach for several reasons: First, our review of extant literature revealed a limited understanding of how firms in a B2B context market supply chainoriented capabilities for managing corporate social responsibility (CSR), and how respective business practices substantiate an enhanced corporate reputation. In such a nascent stage of research, case studies provide a strong means for exploration and theory development purposes, in particular if related constructs are rare and relationships among them are still ambiguously defined (Lee and Klassen 2008). Second, the use of case studies is a method of choice for studying complex phenomena and generating managerial-relevant knowledge (Boyer and Swink 2008; Gibbert, Ruigrok, and Wicki 2008). Finally, case study research allows the re- 
searcher to interact with the informant and draw on multiple sources of information, leading to information-rich cases (Yin 2009) and hence minimizing the social desirability bias inherent in the CSR topic (Crane 1999). In order to mitigate the shortcomings of case study research compared to more formalized methods, such as quantitative theory testing approaches (Adams, Day, and Dougherty 1998; Yin 2009), we systematically developed a research framework to follow at all stages of our research process. Moreover, the use of multiple data sources to evaluate a single phenomenon enables data triangulation and aims to elude the social desirability bias inherent in the sustainability topic (Crane 1999).

\subsection{Case selection and sampling}

Following a theoretical sampling approach, key decisions were made in order to set the boundaries for the population of this research (Yin 2009). The case selection followed a structured process to maximize the richness of information and minimize the number of cases necessary for comprehensive insights (Perry 1998). In order to lessen extraneous variations and to ensure external validity (Wilson and Vlosky 1997), we limited the population to firms from developed countries within the European Union as we assumed homogeneous antecedents for the development of CSR-related business practices, similar environmental and social regulations, and similar cost structures within this region. In particular, our case firms originate from Austria, Germany, and Sweden. As the study focuses on top-tier suppliers and their role in managing upstream subsuppliers towards responsibility, we chose industries in which a major share of value is added beyond top-tier suppliers at the sub-supplier level. We selected packaging and industrial electronics as industries of choice for several reasons: First, we assumed that a research design which covers more than one industry might provide a broader spectrum of supply chain-related CSR practices (Pagell and Wu 2009; Wu and Choi 2005), in order to generalize our results. Second, in both industries firms deliver a limited range of products to a broad range of customers across various countries and industries, which indicate that these suppliers confront a broad range of CSR-related customer demands. Finally, the two selected industries have been the subject of various academic contributions in the context of CSR exploring the use of wood as input material, environmental issues through the use of hazardous materials, as well as social issues related to production processes (Bone and Corey 2000; Kourula 2010; Smith, Sonnenfeld, and Pellow 2006).

Moreover, we narrowed the sampling frame to toptier suppliers (first tier, second tier) that manage a multitier upstream supply chain for their customers even though it is clear from a practical perspective that, due to resource constraints and upstream supply chain complexity, the active management of suppliers is usually limited to the direct supplier stage. Managing the CSR of sub-suppliers is limited to notable exceptions. Since CSR-related business practices are more elaborate in large organizations (Lee and Klassen 2008), we considered the leading firms in the two industries by size and revenue (Howard, Nash, and Ehrenfeld 1999). In this sampling frame, we identified top tiers with a reputation for practicing CSR along the supply chain based on independent sources such as sustainability indices (e.g., FTSE4Good, Dow Jones Sustainability Index), business press articles, and NGO reports, as suggested by Pagell and Wu (2009). Based on these criteria, we approached the relevant top-tier suppliers in the selected business markets through a standardized invitation letter and followed up through emails and phone calls. We added additional cases to our sample until theoretical saturation was reached, as further cases and insights into their business practices would have added only marginal insights (Strauss and Corbin 1998). Overall, we obtained a sample of nine cases, of which the five best-practice cases are presented in this paper. For selecting the best-practice cases, we applied the "crucial case" method (cf., Gerring 2006), which aims to detect those cases in which a predicted outcome - in the context of this research, the identification of best practices in CSR-related marketing and supply management practices - is most likely to occur. After a thorough analysis of all nine case firms, we selected the cases that demonstrated the greatest maturity in their CSR-related business practices in order to strengthen our contribution through reporting on best practices only. For instance, one case was removed since this top-tier supplier's CSR engagement was mainly driven by the regulatory requirements of one of its major customers, while in another case it appeared that despite the supplier's frequent recognition for responsibility, CSR was not explicitly considered in its 
Table 1: Case characteristics (sorted by company size)

\begin{tabular}{|c|c|c|c|c|c|c|}
\hline Firm & Industry & $\begin{array}{l}\text { Size }^{\text {a }} \text { / Own- } \\
\text { er-ship }\end{array}$ & $\begin{array}{l}\text { Part of a } \\
\text { group }\end{array}$ & Main products & $\begin{array}{l}\text { Main customer } \\
\text { markets }^{b}\end{array}$ & Informant job titles \\
\hline$A$ & $\begin{array}{l}\text { Consumer } \\
\text { packaging }\end{array}$ & 8.5 / public & yes & $\begin{array}{l}\text { Packaging containers } \\
\text { Filling systems } \\
\text { Coated paperboard } \\
\text { boxes }\end{array}$ & $\begin{array}{l}\text { 1. Food \& beverage } \\
\text { 2. Consumer goods } \\
\text { 3. Food retailers }\end{array}$ & $\begin{array}{l}\text { 1. Manager Sales } \\
\text { 2. Manager Sourcing \& } \\
\text { Procurement }\end{array}$ \\
\hline$B$ & $\begin{array}{l}\text { Pulp \& Paper / } \\
\text { Packaging }\end{array}$ & 5.0 / public & yes & $\begin{array}{l}\text { Uncoated fine paper } \\
\text { Craftliner paper } \\
\text { Corrugated \& bags }\end{array}$ & $\begin{array}{l}\text { 1. Consumer goods } \\
\text { 2. Paper merchants } \\
\text { 3. Construction }\end{array}$ & $\begin{array}{l}\text { 1. Head of Salesc } \\
\text { 2. Marketing / Sustainability } \\
\text { Manager } \\
\text { 3. Head of Procurement }\end{array}$ \\
\hline C & $\begin{array}{l}\text { Micro- } \\
\text { electronics }\end{array}$ & 3.0 / public & no & $\begin{array}{l}\text { Process control } \\
\text { devices } \\
\text { Microprocessors } \\
\text { Custom devices }\end{array}$ & $\begin{array}{l}\text { 1. Automotive } \\
\text { 2. Power generation } \\
\text { 3. Security }\end{array}$ & $\begin{array}{l}\text { 1. Director Sales / Market. } \\
\text { 2. Director Purchasing } \\
\text { 3. Vice President SCM } \\
\text { 4. Director Sustainability }\end{array}$ \\
\hline$D$ & $\begin{array}{l}\text { Industrial } \\
\text { electronics }\end{array}$ & $2.5 /$ public & yes & $\begin{array}{l}\text { Automation equipment } \\
\text { Control equipment } \\
\text { Building technologies }\end{array}$ & $\begin{array}{l}\text { 1. Power generation } \\
\text { 2. Oil \& gas } \\
\text { 3. Pharma }\end{array}$ & $\begin{array}{l}\text { 1. General Manager / } \\
\text { Head of Salesc } \\
\text { 2. Head of Purchasing }\end{array}$ \\
\hline$E$ & $\begin{array}{l}\text { Carton board } \\
\text { \& Packaging }\end{array}$ & 1.5 / private & yes & $\begin{array}{l}\text { Carton boards } \\
\text { Cartons } \\
\text { Paper products }\end{array}$ & $\begin{array}{l}\text { 1. Tobacco } \\
\text { 2. Consumer goods } \\
\text { 3. Food \& beverage }\end{array}$ & $\begin{array}{l}\text { 1. Head of Marketing } \\
\text { 2. Head of Sourcing } \\
\text { 3. Sustainability Manager }\end{array}$ \\
\hline
\end{tabular}

a) Annual revenue 2009 in billion Euros

b) Sorted by generated revenue

c) Telephone interview

marketing or purchasing practices. Even though the "crucial case" selection is subject to bias, this "selection bias" is on the other hand necessary when identifying best practices. Since our research focuses on the alignment of an industrial firm's CSR marketing with its supply management practices, we chose the sales and marketing function as well as the supply management function as the units of analysis. Additionally, we regarded coordinating functions such as SCM or a CSR department, if present at the case firm. The characteristics of the participating top-tier suppliers are summarized in Table 1.

\subsection{Data collection}

Primary data were collected in two phases between December 2010 and October 2011. Initial expert interviews with primarily executive management representatives led to the identification of appropriate interview partners in the respective business functions to ensure valid and reliable information on the topic. We subsequently approached these identified executives via email and telephone calls. We chose respondents that have been or are currently involved in CSR-related projects or business practices and hence had an understanding of the
CSR-related developments within their firm and the respective function.

In the first phase, we asked each participating firm to complete a brief questionnaire on basic data about the firm, its marketing and purchasing function, and the overall degree to which CSR is integrated in the organization and its functions. The questionnaire was divided into three sections (marketing and alignment, purchasing and alignment, CSR management descriptive), with each section completed by the appropriate candidates prior to the personal interviews. We then compared the questionnaire answers with openly available company documentation, such as sustainability reports or statements on the corporate website, in order to develop guiding and probe questions for the interview guide (Eisenhardt 1989; Perry 1998). Please refer to the appendix for the core questions of the semi-structured interviews.

In the second phase, we conducted semi-structured interviews with the previously identified informants based on the developed interview guide. The interviewed purchasing executives provided insights into the proficiency of their upstream CSR practices, while sales and marketing informants provided insights into the downstream practices. Semi- 
structured interviews lasted one to three hours, and each interviewer took minutes of answers and presented documents, which the authors compared and revised afterwards. Additionally, the interview protocol was sent to each interviewee to rule out any misunderstandings or misinterpretations. Overall, we conducted two to four interviews per case firm. The reliance on multiple respondents enabled us to cross-check responses and to avoid singleinformant bias. Moreover, we supplemented the data collection process with site visits and visits to public events at which the case companies presented themselves, such as trade fairs or symposia. We continuously kept track of our proceedings in a protocol to ensure reliability. Additionally, we developed structured sheets on which we recorded observations made at the company sites or at public events. We stored each observation from different data sources in a case database to enable structured analysis of these large amounts of data (Yin 2009). Please refer to Appendix II for further validity- and reliability-assuring measures undertaken throughout our research process.

\section{Results}

The results section is divided into an explorative and an inductive part. In the exploratory analysis, we investigate how top-tier suppliers organize and market supply chain-oriented capabilities for managing corporate social responsibility (CSR) and how they integrate purchasing and marketing activities in this context. In particular, we explore the suppliers' business practices in the three dimensions of our research framework ([1] supplier-oriented CSR practices, [2] marketing of CSR practices, and [3] CSR-related purchasing \& marketing integration). As the article's main focus is the exploration of distinct concepts for marketing CSR-related SCM practices, and the respective business practices for integrating marketing and purchasing, the exploratory analysis will devote more attention to the second and third dimension of the theoretical framework because the first dimension (Supplier-oriented CSR practices) has already been widely discussed in the extant SCM literature (Krause, Vachon, and Klassen 2009; Pagell and Wu 2009; Paulraj 2011). However, for comprehensiveness, we will also provide a brief overview of the identified business practices in this first dimension of the theoretical framework. To keep the results section succinct, we organized a significant portion of the data analysis into tables. In the second part of the analysis, we inductively analyze how the explored practices in the three dimensions of the framework affect a top-tier supplier's reputation, leading to theoretical propositions on the marketing-reputation link in business markets, and ultimately to an adapted theoretical model on cross-functional integration in the context of CSR.

\subsection{Exploratory analysis: Distinct concepts for marketing CSR}

The exploratory analysis was conducted in two phases: a within-case analysis and a cross-case analysis. The within-case analysis aimed to reduce and manage the large amounts of data collected in order to make sense out of the obtained information and get acquainted with each case (Miles and $\mathrm{Hu}-$ berman 1994). In a first step, we tried to understand each case firm's business model, market position, competitive environment, and buyer-sided demands in the context of CSR. For instance, Firm B, a leading paper and packaging supplier, is operating in a competitive commodity market with powerful buyers in one of its major target markets (food packaging). These buyers are themselves under enormous cost and CSR pressure and, therefore, are not willing to pay a premium for sustainably produced products. However, this group of buyers regularly confronts Firm $B$ with explicit and ambitious targets related to a responsible upstream supply chain. Firm $C$, a semiconductor and microchip supplier, faces strict legal regulations related to production operations and input material, but its customers do not set particular CSR targets. Instead, they implicitly expect their top-tier suppliers to comply with social and environmental standards in their own and their sub-suppliers' business operations as a precondition for being considered as a potential business partner. Yet customers value the green product characteristics of their upstream suppliers.

In a subsequent step, we identified each top-tier supplier's CSR-related purchasing and marketing activities and compared them with extant literature in order to detect novel practices. Moreover, we tried to identify the enablers and constraints that drive and limit each firm's CSR-related efforts and initiatives in order to better understand whether the individual approaches could be extended to other 
Table 2: Individual approaches of case firms towards CSR

\begin{tabular}{|c|c|c|c|c|c|}
\hline Firm & $\begin{array}{l}\text { Market condi- } \\
\text { tions }\end{array}$ & $\begin{array}{l}\text { Strategic } \\
\text { approach } \\
\text { towards CSR }\end{array}$ & $\begin{array}{l}\text { Overall approach } \\
\text { towards market- } \\
\text { ing CSR }\end{array}$ & $\begin{array}{l}\text { Approach to- } \\
\text { wards CSR in } \\
\text { supply man- } \\
\text { agement }\end{array}$ & $\begin{array}{l}\text { Perceived own and cus- } \\
\text { tomer benefits from en- } \\
\text { hanced CSR-related sup- } \\
\text { ply chain capabilities }\end{array}$ \\
\hline$A$ & $\begin{array}{l}\text { Commodity mar- } \\
\text { ket; high regula- } \\
\text { tions and CSR } \\
\text { pressure from } \\
\text { buyers and retail- } \\
\text { ers }\end{array}$ & $\begin{array}{l}\text { Company aims to be } \\
\text { a thought leader } \\
\text { with regards to CSR }\end{array}$ & $\begin{array}{l}\text { Sophisticated marketing } \\
\text { practices; sustainability } \\
\text { is a major part of the } \\
\text { corporate brand }\end{array}$ & $\begin{array}{l}\text { Detached supply } \\
\text { management organi- } \\
\text { zation with strict CSR } \\
\text { regulations }\end{array}$ & $\begin{array}{l}\text { Ability to steer retailer and produc- } \\
\text { er specifications in the companies } \\
\text { favor leads to sales growth; Assur- } \\
\text { ing competition among sub- } \\
\text { supplier leads to better prices in } \\
\text { the medium term; safeguarding } \\
\text { corporate image }\end{array}$ \\
\hline$B$ & $\begin{array}{l}\text { Powerful retailers } \\
\text { and paper mer- } \\
\text { chants; suppliers } \\
\text { lead CSR debate; } \\
\text { high NGO pres- } \\
\text { sure }\end{array}$ & $\begin{array}{l}\text { CSR is a major pillar } \\
\text { of the company's } \\
\text { business strategy }\end{array}$ & $\begin{array}{l}\text { Proactive communica- } \\
\text { tion of CSR efforts re- } \\
\text { lated to social and en- } \\
\text { vironmental responsibil- } \\
\text { ity }\end{array}$ & $\begin{array}{l}\text { Rather reactive CSR } \\
\text { approach and focus } \\
\text { on certifications; } \\
\text { particular emphasis } \\
\text { on social responsibil- } \\
\text { ity }\end{array}$ & $\begin{array}{l}\text { Enhanced greenness of processes } \\
\text { and product ingredients reduces } \\
\text { costs; product price differentiation } \\
\text { based on CSR; customer respon- } \\
\text { siveness leads to customer loyalty; } \\
\text { safeguarding of own and custom- } \\
\text { ers' corporate reputation }\end{array}$ \\
\hline$C$ & $\begin{array}{l}\text { Customers de- } \\
\text { mand innovation; } \\
\text { oligopolistic mar- } \\
\text { ket; compliance } \\
\text { with ethical stand- } \\
\text { ards is regarded as } \\
\text { a "table-stake" }\end{array}$ & $\begin{array}{l}\text { Aims for CSR lead- } \\
\text { ership; listed in } \\
\text { sustainability index. } \\
\text { Engagement in } \\
\text { industry-wide initia- } \\
\text { tives }\end{array}$ & $\begin{array}{l}\text { Focus on sustainability- } \\
\text { related product features } \\
\text { and less emphasis on } \\
\text { marketing of CSR-rela- } \\
\text { ted business practices }\end{array}$ & $\begin{array}{l}\text { Integrated CSR } \\
\text { concept for entire } \\
\text { upstream supply } \\
\text { chain; supplier risk } \\
\text { assessments and } \\
\text { development to CSR }\end{array}$ & $\begin{array}{l}\text { Differentiation through sustainable } \\
\text { product development; safeguard } \\
\text { and enhance relations and order } \\
\text { volume with existing customers; } \\
\text { higher prices for green products } \\
\text { lead to higher margins while mar- } \\
\text { keting seeks sales growth simulta- } \\
\text { neously }\end{array}$ \\
\hline$D$ & $\begin{array}{l}\text { Large, long-term } \\
\text { industrial projects; } \\
\text { focus on innova- } \\
\text { tion, quality and } \\
\text { environmental } \\
\text { CSR }\end{array}$ & $\begin{array}{l}\text { Corporate compli- } \\
\text { ance initiative cover- } \\
\text { ing social / envi- } \\
\text { ronmental responsi- } \\
\text { bility }\end{array}$ & $\begin{array}{l}\text { Promotion of sustaina- } \\
\text { bility-related product } \\
\text { features, focus on envi- } \\
\text { ronmental innovations }\end{array}$ & $\begin{array}{l}\text { Recently started } \\
\text { green supply chain } \\
\text { initiative, focus on } \\
\text { compliance and } \\
\text { supplier risk }\end{array}$ & $\begin{array}{l}\text { Higher customer loyalty as a result } \\
\text { of a close project based collabora- } \\
\text { tion; ability to charge slightly } \\
\text { higher prices for green product } \\
\text { innovations; safeguarding corpo- } \\
\text { rate image and reputation }\end{array}$ \\
\hline$E$ & $\begin{array}{l}\text { Customers set high } \\
\text { CSR targets; } \\
\text { Europe is short of } \\
\text { certified wood and } \\
\text { recycled carton } \\
\text { board }\end{array}$ & $\begin{array}{l}\text { Environmental } \\
\text { responsibility is the } \\
\text { firm's main factor } \\
\text { for differentiation }\end{array}$ & $\begin{array}{l}\text { Markets the cost ad- } \\
\text { vantage of environmen- } \\
\text { tal sustainability, high- } \\
\text { lights thought leader- } \\
\text { ship in environmental } \\
\text { innovation }\end{array}$ & $\begin{array}{l}\text { Focus on supplier } \\
\text { certification. Rele- } \\
\text { vant certification } \\
\text { relies on "chain-of- } \\
\text { custody" principle }\end{array}$ & $\begin{array}{l}\text { Enhanced customer satisfaction } \\
\text { from high service perception; } \\
\text { transparency and the customers' } \\
\text { responsiveness are enhanced; } \\
\text { safeguarding of own and custom- } \\
\text { ers' corporate reputation; Efficien- } \\
\text { cy product differentiation based on } \\
\text { customers' CSR demands. }\end{array}$ \\
\hline
\end{tabular}

top-tier suppliers. Finally, the previous steps were condensed into a tabular display of the case firms' individual approaches to CSR in the upstream and downstream business practices (see Table 2).

The second phase, the cross-case analysis, aimed to identify patterns and commonalities across the case firms by reducing, structuring, and categorizing the available data into a standardized and comparable format (Miles and Huberman 1994; Yin 2009). Therefore, all field data were carefully reviewed in order to highlight important issues and patterns in the CSR-related supply chain practices across our sample firms. Moreover, the interviewees' statements about each framework dimension were organized into text files, and key quotations were noted
(Patton 1990). The cross-case analysis followed a two-step approach: (1) the coding of interviews and condensing to business practices, and (2) the assignment of individual business practices to new concepts. Once all primary and secondary data were collected, we started our open coding procedures in order to structure the information provided by the five case companies. Beginning with the first case, the same procedures were repeated for the four other cases. Subsequently, key business practices were assigned to the dimensions of our research framework by the same two authors. A practice could be assigned to the same or to a different category, which leads us to a binary assessment. E.g., the practice "Target group-specific communication 
of CSR topics' was assigned to 'Customer-oriented CSR practices' but could also have been assigned to one of the other two dimensions. After the first coding round $86 \%(19 / 22)$ of the codes where assigned to the same construct by the two authors. In case of differing allocations of codes, the authors discussed their reasons for the assignment analyzed these reasons and came up with a mutually agreed assignment.

After the assignment of practices to the dimensions of the framework each author assigned axial codes per practice. This refers to the intensity with which these practices were pursued (Yes, No, Limited). This process was individually done by the same two authors leading to $82 \%(18 / 22)$ of inter-rater agreement in the first coding round. The discrepancy on four codes was due to different interpretations of "Yes" and "Limited" as axial codes. Similar to the assignment of the business practices differing interpretations were addressed by discussion leading to mutual agreement on all 22 codes. The authors wrote down a formal comment to justify their change in assessment (Pagell 2004). After the individual firm profiles were obtained from this withincase coding, we conducted cross-case analysis and relied on tabular displays to detect differences and common patterns of upstream CSR processes across firms (Eisenhardt and Graebner 2007; Yin 2009).

In the same fashion as the coding of the business practices, we assigned the individual business practices to the four identified concepts for marketing SCM-related CSR practices. Also in this case, the same two authors mapped the practices to the four concepts individually. After the first round of coding we achieved an $82 \%$ (27/33) match among the two authors. As a consequence, we evaluated differing interpretations and re-assigned the six ambiguously coded practices after mutual agreement was reached. This process led to the development of Table 4, which illustrates the newly identified crosscase practices related to the dimensions of our framework (Eisenhardt and Graebner 2007; Miles and Huberman 1994; Yin 2009).

\section{Table 3: New practices not previously identified by literature on CSR}

\begin{tabular}{|c|c|c|c|}
\hline $\begin{array}{l}\text { Element in } \\
\text { Framework }\end{array}$ & Business practice & Description & $\begin{array}{l}\text { Associated cost (affected } \\
\text { cost dimensions) }\end{array}$ \\
\hline \multirow{2}{*}{$\begin{array}{l}\text { Supplier- } \\
\text { oriented } \\
\text { CSR } \\
\text { practices }\end{array}$} & End-2-end process model & $\begin{array}{l}\text { End-to-end process model for CSR- } \\
\text { related supplier management }\end{array}$ & $\begin{array}{l}\text { - Personnel Cost (Development) } \\
\text { - Process Cost (Deployment) }\end{array}$ \\
\hline & Selective control & $\begin{array}{l}\text { Control of sub-suppliers' CSR compli- } \\
\text { ance only in critical countries }\end{array}$ & $\begin{array}{l}\text { - Personnel Cost (Auditors) } \\
\text { - Process Cost (Deployment) }\end{array}$ \\
\hline \multirow{9}{*}{$\begin{array}{l}\text { Customer- } \\
\text { oriented } \\
\text { CSR } \\
\text { practices }\end{array}$} & Customer education & $\begin{array}{l}\text { Education of customers in CSR-related } \\
\text { topics }\end{array}$ & $\begin{array}{l}\text { - Personnel Cost (Research \& Train- } \\
\text { ing) }\end{array}$ \\
\hline & Customer dialogue & $\begin{array}{l}\text { Open dialogue on CSR with existing } \\
\text { buyers }\end{array}$ & $\begin{array}{l}\text { - Process Cost (Deployment of } \\
\text { customer relationship processes) }\end{array}$ \\
\hline & Research support & Support of CSR research initiatives & - Funding of Research \\
\hline & Usage of mass media & $\begin{array}{l}\text { Placement of CSR-related advertise- } \\
\text { ments targeting end consumers }\end{array}$ & - Marketing Cost \\
\hline & CSR in company slogan & $\begin{array}{l}\text { Responsibility is key message of compa- } \\
\text { ny slogan }\end{array}$ & - Marketing Cost \\
\hline & Additional product services & $\begin{array}{l}\text { Information on product disposal deliv- } \\
\text { ered to buyers }\end{array}$ & $\begin{array}{l}\text { - Marketing Cost } \\
\text { - Process Cost }\end{array}$ \\
\hline & $\begin{array}{l}\text { Certification of communica- } \\
\text { tion }\end{array}$ & $\begin{array}{l}\text { Certification of CSR communication } \\
\text { according to a DIN ISO norm }\end{array}$ & $\begin{array}{l}\text { - Certification Cost } \\
\text { - Transformation Cost } \\
\text { - Process Cost }\end{array}$ \\
\hline & Benefit case provision & $\begin{array}{l}\text { Product offers contain an ROI calcula- } \\
\text { tion for ecological innovations }\end{array}$ & $\begin{array}{l}\text { - Personnel Cost } \\
\text { throcess Cost (ROI calculation R\&D, Engineering) }\end{array}$ \\
\hline & $\begin{array}{l}\text { Challenging of customer } \\
\text { requirements }\end{array}$ & $\begin{array}{l}\text { Challenging customer's ecological re- } \\
\text { quirements }\end{array}$ & $\begin{array}{l}\text { - No cost associated (Regular sales } \\
\text { process) }\end{array}$ \\
\hline
\end{tabular}


Table 3 continued: New practices not previously identified by literature on CSR

\begin{tabular}{|c|c|c|c|}
\hline $\begin{array}{l}\text { Element in } \\
\text { Framework }\end{array}$ & Business practice & Description & $\begin{array}{l}\text { Associated cost (affected } \\
\text { cost dimensions) }\end{array}$ \\
\hline \multirow{3}{*}{$\begin{array}{l}\text { Customer- } \\
\text { oriented } \\
\text { CSR } \\
\text { practices }\end{array}$} & $\begin{array}{l}\text { Gain-share contracts for } \\
\text { CSR promotion }\end{array}$ & $\begin{array}{l}\text { Gain-share contracts offered to buyers if } \\
\text { investing in environmental innovations }\end{array}$ & $\begin{array}{l}\text { - Opportunity cost } \\
\text { - Process cost (for calculation and } \\
\text { maintenance of benefit case) }\end{array}$ \\
\hline & Regulatory support & $\begin{array}{l}\text { Support buyers in obtaining CSR- } \\
\text { related certifications and in fulfilling } \\
\text { regulatory requirements }\end{array}$ & - Personnel Cost (Support) \\
\hline & Provision of market place & $\begin{array}{l}\text { Online discussion board on responsibil- } \\
\text { ity for customers }\end{array}$ & $\begin{array}{l}\text { - IT Cost } \\
\text { - Personnel Cost }\end{array}$ \\
\hline \multirow{8}{*}{$\begin{array}{l}\text { Marketing- } \\
\text { Purchasing } \\
\text { integration }\end{array}$} & Full-time CSR managers & $\begin{array}{l}\text { Employment of full-time sustainabil- } \\
\text { ity/CSR manager }\end{array}$ & - Personnel Cost \\
\hline & Divisional CSR targets & $\begin{array}{l}\text { Measurable corporate \& divisional CSR } \\
\text { targets }\end{array}$ & - No cost associated \\
\hline & Corporate CSR teams & $\begin{array}{l}\text { Deployment of a corporate sustainabil- } \\
\text { ity/CSR team }\end{array}$ & - Personnel Cost \\
\hline & CSR-demand routing & $\begin{array}{l}\text { Purchasing is driven by CSR-related } \\
\text { demand forecasts from marketing }\end{array}$ & $\begin{array}{l}\text { - IT Cost } \\
\text { - Process Cost }\end{array}$ \\
\hline & $\begin{array}{l}\text { Cross-functional CSR con- } \\
\text { cepts }\end{array}$ & $\begin{array}{l}\text { Cross-functional CSR concept for all } \\
\text { steps of value chain }\end{array}$ & - Personnel Cost (set up concept) \\
\hline & Assisted supplier evaluation & $\begin{array}{l}\text { Sustainability/CSR department sup- } \\
\text { ports supplier evaluation }\end{array}$ & $\begin{array}{l}\text { - Personnel Cost } \\
\text { - Process Cost } \\
\text { - IT Cost (if supported by system) }\end{array}$ \\
\hline & $\begin{array}{l}\text { Purchasing integration in } \\
\text { product design }\end{array}$ & $\begin{array}{l}\text { Cross-functional initiatives for sustaina- } \\
\text { ble product design }\end{array}$ & $\begin{array}{l}\text { - Personnel Cost } \\
\text { - Transformation Cost }\end{array}$ \\
\hline & Trend scouts for CSR & $\begin{array}{l}\text { Deployment of scouts for gathering } \\
\text { CSR-related market trends }\end{array}$ & - Personnel Cost \\
\hline
\end{tabular}

Please refer to Appendix III for an illustration of those identified practices that previously appeared in the literature, eventually in a different context but not necessarily in a B2B supply chain context. In particular, the practices identified in the context of the first dimension of the research framework (Supplier-oriented CSR practices) match to great extent what has been previously identified in the SCM literature.

Table 3 illustrates those practices emerging from the cross-case analysis, which to the best of our knowledge have not yet been mentioned in the context of CSR and which are specific to upstream and downstream SCM and the purchasing and marketing functions' alignment. In order to combine these novel practices with the existing knowledge to larger concepts for marketing superior CSR-related SCM capabilities, we rearranged known and newly identified practices in an iterative process. We then created additional insights by looking for dimensional practices that are interlinked with practices from other dimensions. Thus, we subsequently combined these selected practices from all three dimensions in distinct concepts for marketing CSR-related SCM capabilities to downstream customers (see Table 4). For instance, in the first concept, Fact-based communication of measurable CSR capabilities, we linked buyer- and supplier-oriented CSR practices with practices related to purchasing-marketing integration as this concept represents a truly crossfunctional exercise. To successfully perform this practice, our case firms showed the existence of measurable supplier-oriented business practices that are in a subsequent step converted into adequate, target-group-specific marketing messages through a close collaboration between the two functions. In summary, the grouping process of the structured cross-case business practices led to the identification of four distinct concepts for marketing CSR-related supply chain capabilities. 


\section{Table 4: Concepts for marketing CSR derived from identified practices}

\begin{tabular}{|c|c|c|}
\hline Concept & Description & $\begin{array}{l}\text { CSR-related business practices from Tables } 4 \text { and } 5 \text { contributing } \\
\text { to each bundle }\end{array}$ \\
\hline \multirow{10}{*}{$\begin{array}{l}\text { Bundle 1: } \\
\text { Fact-based com- } \\
\text { munication of } \\
\text { measurable CSR } \\
\text { capabilities }\end{array}$} & \multirow{10}{*}{$\begin{array}{l}\text { Company communi- } \\
\text { cates measurable } \\
\text { facts of its CSR- } \\
\text { related business } \\
\text { practices to the } \\
\text { market }\end{array}$} & $\begin{array}{l}\text { Purchasing: Traceability concept for determining the origin of raw } \\
\text { material }\end{array}$ \\
\hline & & Purchasing: Defined processes in case of supplier misconduct \\
\hline & & Purchasing: Suppliers need to own CSR-related certifications \\
\hline & & Marketing: Promotion of CSR-related product features or product lines \\
\hline & & Marketing: Sustainability report covering the triple bottom line \\
\hline & & Marketing: Promotion of green product lines sold at higher prices \\
\hline & & Marketing: Research support \\
\hline & & Marketing: Certification of communication \\
\hline & & Integration: Divisional CSR targets \\
\hline & & Integration: CSR-demand routing \\
\hline \multirow{7}{*}{$\begin{array}{l}\text { Bundle 2: Target- } \\
\text { ing of indirect } \\
\text { customers and } \\
\text { influencers }\end{array}$} & \multirow{7}{*}{$\begin{array}{l}\text { The top-tier suppli- } \\
\text { er's marketing mes- } \\
\text { sages aim not only at } \\
\text { direct customers } \\
\text { such as buyers, but } \\
\text { also target indirect } \\
\text { stakeholders }\end{array}$} & Purchasing: Measurement of the supply chain's carbon footprint \\
\hline & & Marketing: Joint CSR initiatives with NGOs driven by marketing \\
\hline & & Marketing: Customer dialogue \\
\hline & & Marketing: Usage of mass media \\
\hline & & Marketing: CSR in company slogan \\
\hline & & Integration: Assisted supplier evaluation \\
\hline & & Integration: Trend scouts for CSR \\
\hline \multirow{7}{*}{$\begin{array}{l}\text { Bundle 3: Market- } \\
\text { ing through educa- } \\
\text { tion }\end{array}$} & \multirow{7}{*}{$\begin{array}{l}\text { Use thought leader- } \\
\text { ship in CSR-related } \\
\text { topics for customer } \\
\text { education which in } \\
\text { turn reflects on the } \\
\text { suppliers' capabili- } \\
\text { ties in this context }\end{array}$} & Marketing: CSR information at top of corporate website \\
\hline & & Marketing: CSR-related info material for external \& internal use \\
\hline & & Marketing: Active positioning as CSR innovator \\
\hline & & Marketing: Customer education \\
\hline & & Marketing: Provision of market place \\
\hline & & Integration: Assisted supplier evaluation \\
\hline & & Integration: Education of workforce in CSR-related topics \\
\hline \multirow{9}{*}{$\begin{array}{l}\text { Bundle 4: Market- } \\
\text { ing of CSR as a } \\
\text { service }\end{array}$} & \multirow{9}{*}{$\begin{array}{l}\text { Use CSR-related } \\
\text { capabilities in the } \\
\text { sense of a business } \\
\text { services and use } \\
\text { value-adding CSR } \\
\text { capabilities for } \\
\text { supporting buyers }\end{array}$} & Purchasing: Development of suppliers towards CSR (e.g., certifications) \\
\hline & & Purchasing: Supplier risk management processes reflect CSR-related risks \\
\hline & & Marketing: Challenging customer's ecological requirements \\
\hline & & Marketing: Additional product services \\
\hline & & Marketing: Active positioning as CSR innovator \\
\hline & & Marketing: Benefit case provision \\
\hline & & Marketing: Regulatory support \\
\hline & & Integration: Purchasing integration in product design \\
\hline & & Integration: Cross-functional CSR concepts \\
\hline
\end{tabular}




\subsubsection{Concept 1:Fact-based communication of measurable CSR capabilities}

All case firms demonstrated a high level of maturity in managing their upstream supply chain towards sustainability. Hence, they invested heavily into compliance concepts, measures, and controls, certification and audit processes, as well as IT systems in the last three to five years. Moreover, all case companies show a strong capability to ensure a responsible upstream supply chain and also received public recognition for these efforts. For instance, Firm $B$ was mentioned in several business press articles for its top ranking in a popular NGO's report on ecological and social supply chains. Nevertheless, we also discovered that the top-tier suppliers act carefully when communicating and marketing their own CSR capabilities to the business market. As demands for responsibility vary significantly across customer segments, the top-tier suppliers in our sample demonstrated high sensitivity to the individual buyer-sided CSR requirements when deciding how to communicate their achievements publically.

Overall, we found that in a B2B context CSR-related marketing is based on the careful promotion of measurable hard facts such as green product features, business processes, or certifications, rather than on image-building campaigns such as corporate giving or community involvement. CSR communication is thus closely tied to the regular business activities of the firms in our sample. As the reduction of reputational risk is one of the top-tier supplier's key sales messages when marketing CSR, many interviewees stated that the success of marketing CSR in B2B markets stems from their own ability to "walk their CSR talk." Thus, they must make sure that they are always able to prove their promoted CSR-related capabilities through measurable facts. A key enabler for realizing this fact-based CSR marketing approach is the cross-functional integration between marketing and purchasing. On the one hand, the sales side needs to be aware of supplier-oriented CSR management practices to provide a realistic picture to the buyer side. On the other hand, purchasing needs to be aware of the buyer-sided CSR demands in order to derive suitable measures for managing the supply chain towards clients' responsibility demands and specifications. As a result, all top-tier suppliers in our sample deploy a CSR manager or even a separate CSR function that centrally coordinates and aligns the organization's CSR-related activities. On the one hand, these central units support the purchasing function in identifying suitable practices for managing a responsible supply chain, such as CSR-oriented supplier selection criteria, audits, or written regulations for responsible purchasing. On the other hand, the CSR functions provide marketing with valuable hard facts from the supply chain level, such as currently followed supplier development initiatives or the percentage of certified sub-suppliers, which are subsequently converted into marketing messages. For instance, at Firm $C$, a sustainability department coordinates all external communication with regards to CSR while supporting marketing and purchasing with CSR-related business concepts such as the prequalification of potential suppliers based on environmental and social criteria or CSR-related risk assessments of sub-suppliers. At Firm $A$ the sustainability function only recently started to support marketing in certifying its CSR-related communication strategy according to a DIN ISO norm, which regulates the publication of sustainabilityrelated activities and achievements, in order to prevent the accusation of greenwashing.

\subsubsection{Concept 2: Targeting of indirect customers and influencers}

The second bundle of practices is related to the concept of targeting indirect customers with their CSR initiatives. In our analysis we observed that a number of buyer-oriented business practices, such as joint initiatives with NGOs, TV ads, or a company slogan that suggest responsible business behavior, do not directly target existing or potential buyers. Instead, they target other external stakeholders such as NGOs, end-consumers, retailers, or legal authorities. The data revealed that for top-tier suppliers CSR-related requirements do not necessarily originate from their direct buyers but from other external stakeholders such as end-consumers, retailers, NGOs, or legal authorities. The direct customers simply pass these requirements on to their top-tier suppliers. Hence, the top-tier suppliers developed internal capabilities to actually sense these requirements by trying to understand the needs of not only direct buyers but also of other players downstream the supply chain. The top-tier suppliers in our sample tackle this latent CSR demand through proactive management of the respective requirements and by considering them in the development of their CSRrelated business practices. They even go one step beyond and apply marketing practices that actually 
target the needs of their customers' customers, a concept that to the best of our knowledge is novel in the context of CSR and business markets. For instance, Firm A, a food- and beverage-packaging supplier, places TV commercials to educate endconsumers about ecologically friendly behavior and waste management, and thus indirectly promotes the benefits of sustainable packaging. Notably, Firm $A$ 's direct customers are actually located two levels further upstream the supply chain, with retailers and food producers in between. In a similar vein, but using a slightly different strategy, Firm $D$, an industrial electronics supplier, markets its innovative approach for managing sub-supplier-induced CSR risk to a legal institution that evaluates the social and environmental impact of industrial equipment actually delivered by Firm D's customers.

Overall, the concept of targeting indirect customers and other influencers demonstrates a high level of sophistication in effectively marketing CSR in B2B markets and underpins the top-tier suppliers' deep understanding of CSR-related mechanisms in buyer-supplier relationships. Also in the case of this particular concept, the integration of marketing with other business functions is a key for converting indirect customer demands into respective upstream business practices. For instance, in the case of Firm $C$, the central sustainability department coordinates all activities of the individual business functions and regularly initiates cross-functional projects in order to develop such complex indirect CSR marketing approaches.

\subsubsection{Concept 3: Marketing through education}

Throughout the analysis it appeared that the toptier suppliers in our sample invested heavily in thought leadership related to CSR in general and in responsible SCM in particular. For instance, Firm $A$ and Firm $B$ support various research initiatives on responsible SCM. Moreover, Firm $E$ sets up and administers an online discussion board on responsibility in SCM in which Firm Es experts support existing buyers as well as representatives from other companies in CSR-related questions and provide practical hints on CSR management in business markets. Firm $E$ also regularly organizes seminars and roundtables on CSR to educate its buyers and other market participants on these topics. From a marketing perspective, the top-tier suppliers use these education approaches for demonstrating their awareness of and capabilities in CSR. The respondents in our sample stated that even though CSRrelated pressure mainly originates from the buyer side, these claims are often of an abstract nature, and in many cases it is the supplier's task to convert this abstract demand into adequate business practices, which indicates that top-tier suppliers seem to lead this debate. For instance, Firm A's manager sourcing and procurement notes in this context:

"We consider ourselves as a leading company in terms of sustainability-related knowledge and, therefore, educate our customers and even retailers in this field by suggesting possible solutions for acting responsibly. Hence, we remain active regarding this topic and avoid situations in which we have to react to unexpected demands."

Firm A's sales manager confirms:

"We have a first-mover advantage in terms of sustainability. Therefore, we are able to deliberately motivate the sustainability agenda of endconsumers and buyers at an early stage. Our internal and external education initiatives help us to shape the market, enabling us to remain in the driver's seat."

In sum, it appears that top-tier suppliers strategically use their CSR-related knowledge advantage for marketing purposes. Apart from the positioning effect, this concept also enables top-tier suppliers to indirectly influence their buyers' CSR agendas, for example, by highlighting particular facets of CSR that match with the supplier's offering portfolio. Again, a major antecedent for this concept is a close collaboration between the marketing and purchasing functions, as the knowledge on managing the existing upstream supply chain towards responsibility is mainly concentrated in the top-tier supplier's purchasing department, which selects, manages, and develops the downstream suppliers.

\subsubsection{Concept 4: Marketing of CSR as a service}

The fourth distinct concept in CSR-related marketing is the marketing of upstream CSR capabilities as an additional service to customers. The top-tier suppliers in our sample use their market-sensing capabilities to assess their customers' individual CSR needs, then transform these needs into own operations, and finally market this capability as CSR services. For instance, Firm D, the industrial electronics equipment supplier that is often involved in large-scale engineering projects, offers to leverage its experience in certifying sub-suppliers to support 
buyers in certifying their plants according to established environmental standards. As CSR-related certifications often rely on a chain-of-custody principle, which means that every stage of the supply chain including the raw material supplier needs to be certified according to the same standard, the toptier suppliers Firm $B$ and Firm $E$ meanwhile often take over large portions of this certification process for their buyers. Through this add-on service, which is associated with own investments and direct costs, top-tier suppliers safeguard their competitive position in the supply chain since this offering also creates some buyer dependence on the top-tier supplier.

Overall, such a service-dominant logic, as already established in the context of SCM (cf., Lusch 2011) and which has also been discussed in the context of cross-functional processes related to marketing (Lambert and García-Dastugue 2006), is novel in the context of CSR, in particular when considering that a few levels upstream the supply chain external CSR pressure is converted into value-creating services for downstream business partners. These CSRrelated business practices require an even closer integration of the marketing function with other business functions. However, in the case of a CSR service related to the upstream supply chain, such as CSR-related supplier risk assessments, the purchasing function ultimately executes the related business practices and therefore needs to be well aware of the buyer-sided requirements and expectations. Even though our study, due to its explorative design, cannot reveal whether such a service-dominant logic actually leads to additional revenues and new business partners, we argue that this CSR service is a differentiating factor from competitors, which might ultimately lead to additional business with existing customers and tie these customers to the firm. In addition, this service might attract those buying firms that had negative experiences with other suppliers in the industry.

In summary, our analysis revealed that the marketing of supply chain-oriented CSR management capabilities requires a deep understanding of the downstream supply chain (buyers, end-consumers) and exceptional knowledge on how to achieve responsibility in the upstream supply chain (subsuppliers, raw-material suppliers). The four distinct concepts demonstrate approaches on how to market a supply chain-oriented CSR-management capability to existing buyers as well as to the business mar- ket. In combination, the first concept of fact-based marketing sets the basis for all other concepts as in the context of business markets with its professional purchasers the presentation of hard facts in conjunction with promoting superior CSR management capabilities is vital in order to avoid the perception of greenwashing which would potentially offset the positive effects of the marketing attempts. The effectiveness of the remaining concepts largely depends on the particular requirements of existing and potential buyers, as well as on the industry-wide interest in CSR-related business practices. In fact, Concept 2 (Targeting of indirect customers and influencers) and Concept 3 (Marketing through education), and the associated business practices have been more mature among those top-tier supplier that experience high external CSR pressure (Firm $A$, Firm $B$ and Firm E), whereas the concepts are less developed at Firm C and Firm D.

\subsection{Inductive analysis: How the marketing of CSR affects reputation}

In the following, we will discuss how the business practices associated with the previously identified four concepts for marketing CSR-related SCM capabilities affect a top-tier supplier's reputation. In particular, we rely on the basic notion of signaling theory that positive signals enhance a firm's reputation while negative signals harm it and that the consistency in the sent signals is a key enabler for a positive reputation and a stable corporate identity (Cornelissen, Haslam, and Balmer 2007). Hence, we interpret the explored business practices as signals that are sent to existing buyers and the business market. In this context, the CSR-related marketing practices are interpreted as actively sent signals, whereas supplier-oriented business practices are interpreted as measures that aim to avoid the sending of primarily negative signals, for example, through publically reported misconduct on the subsupplier level. Thus, reputational effects were measured indirectly by analyzing the nature and the intensity of sent signals. Thus, signaling serves as a proxy and a mediator for assessing the effect of CSR-related business practices on reputation. In order to ensure external validity and objectivity, we triangulated the marketing representatives' responses on the effects of their CSR-related marketing efforts on their reputation in the marketplace with industry reports, NGO reports, and articles in the business press, which served as an additional 
Figure 2: Theoretical framework extended by CSR marketing-reputation effects

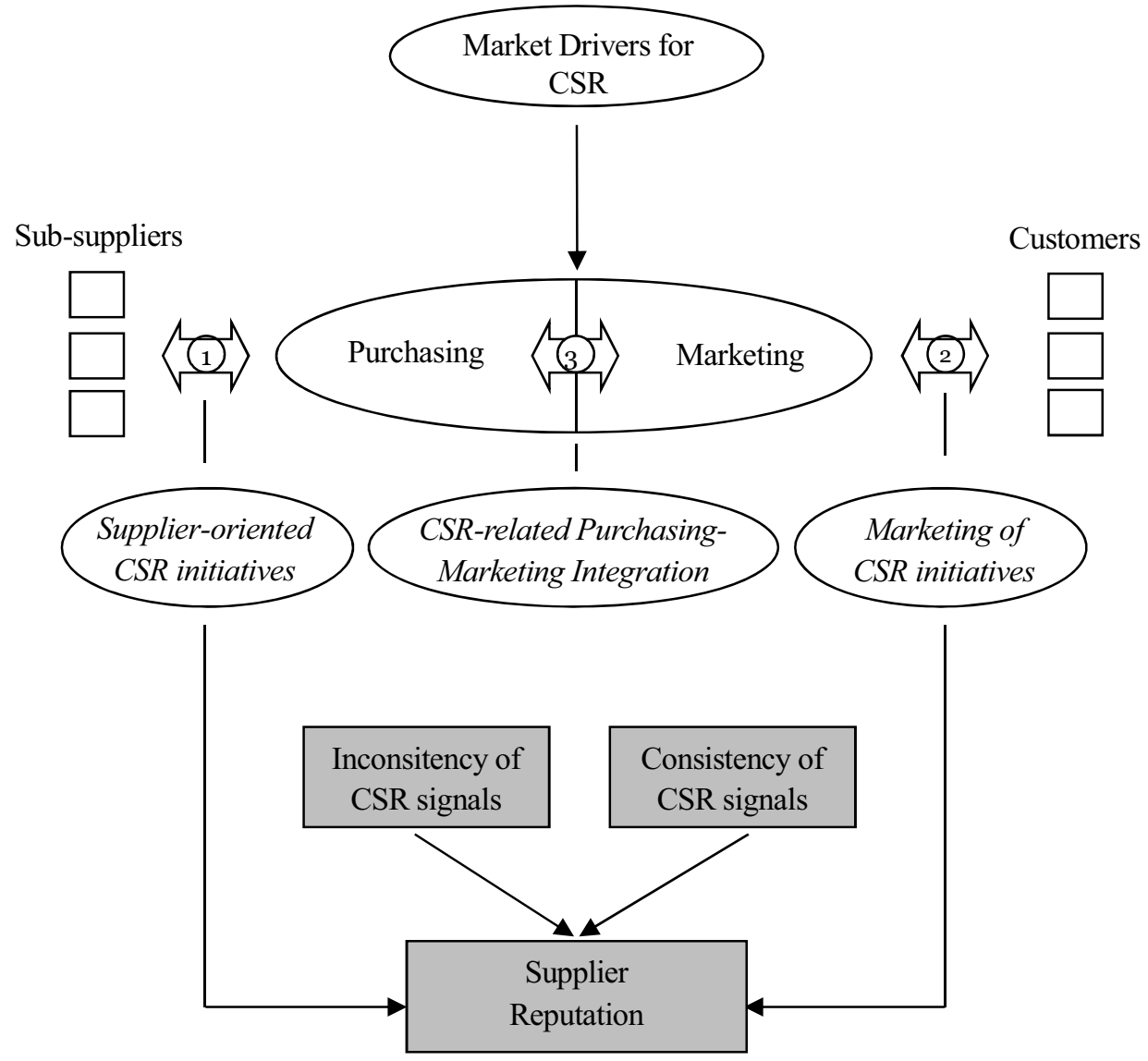

= Components initial model (modified from Sheth, Sharma, and Iyer 2009)

$=$ Components added after empirical analysis of cases

proxy of this perception. For instance, we investigated whether the case firm's customers appreciate extraordinary CSR performance based on so-called supplier awards. Moreover, top-tier suppliers provided us with insights into their own customer satisfaction surveys, which gave us a good indication of the buyer's appreciation for their CSR practices. Figure 2 presents an extended version of our theoretical research framework that incorporates the key assumptions related to signaling theory while at the same time providing an overview of our propositions, which we will elaborate on in the following.

\subsubsection{Reputation-building through marketing of CSR}

From a signaling theory perspective, the identified buyer-oriented CSR practices such as joint initiatives with NGOs (applied by Firm A, Firm B, Firm $E$ ), the support of publically reported research initiatives in the cases of Firm A, Firm B, and Firm D, or an open dialogue on CSR with existing buyers as initiated by Firm $B$ and Firm E, send positive signals on CSR to the business market. Our respondents stated that the marketing of supplier-oriented CSR capabilities is positively reflected by buyers, as they consider supplier- or sub-supplier-induced 
environmental or social misconduct a major reputational threat. As an example, Firm E's head of sales points to the value of CSR as a major differentiator on the market:

"We consider CSR a unique selling proposition among our most important customers. However, most of our customers do not know yet how responsible Firm $E$ really is. Marketing, therefore, has to ensure that our emphasis on CSR is communicated properly."

In a similar vein, Firm C's vice president of SCM notes about the effects of CSR marketing:

"The effect of a positive perception related to responsibility [...] is that the customer's buying managers have higher trust in their supplier and do not have to worry about potential responsibility issues at this part of the supply chain."

Hence, the positive signals sent out to the market seem to build up trust. However, in some cases they are simply a way of demonstrating awareness with particular compliance requirements, as a number of buyers only recently extended their set of supplier selection criteria to social and environmental factors. In this context, Firm D's head of purchasing notes:

"Meanwhile, our customers implicitly expect us to fulfill social and environmental regulations, as these factors are now a regular part of their initial supplier questionnaires and audits, even though they do not explicitly demand responsible business processes." However, the simple equation that more marketing leads to more positive signals and hence to a constantly increasing reputation would not apply to the context of CSR in business markets, as a too radical promotion of one's own capabilities can easily create suspicion and the perception of greenwashing. The previously identified concept of fact-based marketing demonstrates the top-tier suppliers' awareness of the sensitivity of CSR-related marketing attempts in order to avoid that too many positive signals are actually converted into a negative signal. Firm B's initiative of actually certifying its CSR-related communication strategy according to a DIN ISO norm underpins the fact that in business markets with professional purchasers, responsibility marketing is an optimization problem of selling but not overstating one's own CSR capabilities.

All in all, our data confirm that CSR-related marketing initiatives create positive signals, as long as they are sound and targeted to the individual requirements of existing and potential buyers, which is in line with signaling theory's basic notion that receivers of signals need to actually be interested in CSR in order to detect the sent signals (Jones, ClarkeHill, Comfort, and Hillier 2008; Schueth 2003). As a constant sending of positive signals enhances reputation (Cornelissen, Haslam, and Balmer 2007), we argue that a careful and fact-based marketing of own CSR capabilities is beneficial. Thus we formally propose:

Proposition 1a: In business markets the targetgroup-specific marketing of upstream CSR initiatives increases the reputation of a top-tier supplier.

Proposition 1b: In business markets, purely image-building campaigns that are not supported by measurable hard facts have no effect on the reputation of a top-tier supplier.

\subsubsection{Required consistency of marketed and delivered CSR performance}

Another point that emerged from our cross-case analysis was that in B2B markets top-tier suppliers need to ensure that they "walk their CSR talk" in order to convince professional purchasers of their CSR management capabilities. As mentioned in the exploratory analysis, the respondents in our sample widely agreed that consistency between marketing messages and their CSR capabilities is vital in order to be able to benefit from the marketing of such capabilities. Otherwise, perceived overstatement (greenwashing) of their CSR-related supply chain capabilities might become a liability. A close collaboration between marketing and purchasing is central to ensure this consistency, as Firm C s sustainability manager confirms:

"In terms of CSR, the mentioned functions [purchasing and marketing] interact with the support of the corporate sustainability function, which acts as an interface for all sustainability-related topics. Hence, we ensure a consistent external picture that does not exaggerate our CSR capabilities along the supply chain to prevent reputational damage."

In a similar vein Firm Es head of marketing mentions the integration of purchasing and marketing as a cornerstone to turn their supply chain-oriented CSR management capability into a competitive advantage.

"Marketing needs to ensure that facts and numbers are available [...] in order to avoid the perception of greenwashing. Purchasing and marketing, therefore, need to collaborate closely." 
By employing dedicated CSR managers that are in many cases supported by an additional team of up to five full-time employees (in the case of Firm C), all top-tier suppliers in our sample demonstrate that cross-functional integration in CSR-related topics is core to effectively managing responsibility upstream and downstream the supply chain.

From a signaling theory perspective, the crossfunctional integration of purchasing and marketing is necessary for sending consistent signals to the market, which in turn enables the development of a stable corporate identity (Cornelissen, Haslam, and Balmer 2007). For instance, the marketing of reliable supplier-focused mechanisms based on performance indicators such as chain-of-custody-based certifications or the attainment of CSR-related subsupplier audits demonstrates the top-tier supplier's true commitment to CSR (Shrivastava 1995) and enables the marketing function to signal their CSR capability based on measurable facts. Moreover, the close collaboration between marketing and purchasing enables the firms to react timely to cases of subsupplier social or environmental misconduct. Properly communicating and rectifying the misconduct prevents the top-tier supplier from exacerbated market reactions to own or sub-supplier wrongdoing (Janney and Gove 2011).

Nevertheless, we did observe inconsistencies between marketing and purchasing when signaling CSR to the B2B market. While some firms in our sample simply did not seek to market their profound capabilities to specific customer groups, others deliberately overstated their upstream CSR capabilities to customers. For instance, Firm $C$ does not put a lot of emphasis on marketing its outstanding supply chain-oriented CSR management capabilities, yet it applies profound supplier-oriented CSR practices and was identified as the top-tier supplier with the largest CSR department. Moreover, the firm was recently listed in a major sustainability index. Hence Firm $C$ seems to understate its own capabilities. In fact, this understatement leads to a consistent external picture between upstreamand downstream-oriented CSR practices. On the other hand, Firm $E$ only recently started with certification initiatives and only lately extended its regular supplier audits by CSR-related criteria while already engaging strongly in marketing these capabilities. Hence, Firm $E$ seems to overstate its own capabilities. It appeared that purchasing was not aware of the marketing messages, while marketing was not fully aware of the status of the upstream CSR management capabilities prevalent in the purchasing function. Moreover, the CSR-related marketing-purchasing link is less advanced than in other firms in our sample. Although Firm $E$ has a CSR manager, this is only a part-time role and is not supported by additional resources, which also limits the integration of marketing and purchasing in the context of CSR.

Hence, it seems that the consistency of signals depends on how close marketing and purchasing collaborate in the context of CSR on a daily basis and also on the individual CSR requirements of the toptier supplier's various buyers. Our data further suggest that the central CSR functions are the key for integrating the CSR-related purchasing practices with the marketing practices, and that inconsistency in sent signals occurred most frequently when the integration of purchasing and marketing was low. Based on these findings, we propose the following:

Proposition 2a: The higher the level of integration of purchasing and marketing is at a top-tier supplier in the context of CSR, the stronger the incremental rise in the firm's reputation.

Proposition 2b: The lower the level of integration of purchasing and marketing is, the higher the risk of harming reputation.

Even though signaling consistency mediates the effect of upstream CSR capabilities on corporate reputation in the long run, we also found that shortterm incentives for the marketing function to greenwash prevail, as in the case of Firm E, but also similarly for Firm B. Thus, we observed that some top-tier suppliers signaled proficiency and a service offering they were simply unable to provide at the time. However, in the stated cases the buyer-sided pressure for CSR was high and dominated by strong demands and ambitious CSR targets for the suppliers. However, due to the complexity of the upstream supply chain and the relatively weak CSR proficiency on the buyer side, the top-tier suppliers were perceived to benefit from this practice despite an immature focus on CSR inherent in their purchasing practices and the reputational risk associated with this practice. However, such unethical behavior is likely to backfire at the firm over time if it does not commit to upstream CSR and build up the required capabilities. As a result, Firm $B$ and Firm $E$ decided to start matching upstream CSR compli- 
ance with the buyer's particular demands and to catch up with their marketing commitments in a continuous improvement process. Thus, we posit:

Proposition 3a: A short-term overstatement of one's own CSR capabilities increases a top-tier supplier's reputation on the business market even if the buyer's CSR capabilities are immature.

Proposition 3b: The longer the inconsistent signals prevail, the greater the potential for a negative impact on reputation if the overstatement is detected.

\subsubsection{Avoidance of reputational damage through supply chain induced misconduct}

Finally, when shifting the focus from customeroriented CSR practices to supplier-oriented CSR practices, our data reveal that the sending of positive signals through marketing and the avoidance of negative signals through respective SCM practices are in fact two sides of the same coin. Even though positive signals enhance reputation, negative signals through social or environmental misconduct within or beyond one's own corporate boundaries can significantly harm the top-tier supplier's reputation. The negative consequences outweigh the gains of previous positive signals by far. For instance, a few years ago Firm $D$ was involved in a bribery scandal among its suppliers and sub-suppliers. The public interest in the scandal was widely reported in the business press. Moreover, Firm $D$ became the subject of several NGO reports, which severely harmed the firm's reputation and the buyer's trust. Large investments in compliance and CSR followed, but to date Firm $D$ still needs to act very carefully when using CSR-related topics in its external communication and appearance. As a result, Firm $D$ puts higher emphasis on supplier-oriented business practices as it needs to avoid sending negative signals related to responsibility.

Overall, the top-tier suppliers in our sample are aware of the impacts of negative signals on themselves and their customers. Thus, they use their supplier-oriented CSR management practices to avoid the appearance of such negative signals also at the level of their buyers. In this context, Firm Ess head of sales notes:

"We recognized that in particular retail companies our buyers' customers are pushing the responsibility topic forward, driven by a broader public interest for responsible products and operations, as well as by recent scandals in the retail sector and cases of social misconduct at the raw material level. The knowledge about these facts helps us to identify appropriate CSR initiatives on the supplier level that help our buyers in serving their customers' demands in this context."

However, the identified supplier-oriented CSR management initiatives are often associated with high additional costs for the top-tier supplier. For instance, for packaging suppliers the Forest Stewardship Council (FSC) standards require a longlasting certification process that also includes the certification of all suppliers upstream the supply chain to the level of the raw-material supplier. Nevertheless, our data suggest that top-tier suppliers are willing to invest in such practices to avoid misconduct at the sub-supplier level, as this would also ruin all CSR-related marketing efforts. Firm D's head of sales notes:

"Customers come to us as supplier of choice when looking for new (greener) technology, and in order not to jeopardize this image we must assure high standards along the entire supply chain."

Some top-tier suppliers may use their capability to minimize the probability of sending negative signals as a factor for differentiation, for instance if their existing buyers lack the required knowledge for managing a responsible supply chain and are hence dependent on the top-tier supplier's CSR-related gatekeeper services. Firm A's sales manager notes: "Currently, suppliers like us are leading the discussion on sustainability with our customers, as the market pressure for acting responsibly only recently increased. As a result, knowledge on how to manage the upstream supply chain towards responsibility is still at a moderate level among our customers, which makes them partly dependent on us."

From a signaling theory perspective, each negative signal harms a firm's reputation (Cornelissen, Haslam, and Balmer 2007), so supplier-oriented CSR capabilities help top-tier suppliers to avoid situations in which they become the subject of such negative signals. However, supplier-oriented CSR practices themselves do not necessarily enhance a toptier supplier's reputation. Instead, they simply aim to not harm the status quo, even though the avoidance of negative signals is valued higher than the sending of positive signals. As cases of CSR-related misconduct can occur in complex supply networks despite the proactive management through top-tier suppliers, genuine upstream CSR practices can help 
to minimize both their frequency and severity. Moreover, theory suggests that it is not necessary to rule out all misconduct upstream the supply chain, but to credibly signal and demonstrate that one is capable of addressing supplier misconduct (Cornelissen, Haslam, and Balmer 2007; Janney and Gove 2011). Hence, we propose:

Proposition 4a: In business markets, supplieroriented CSR practices reduce the destructive effects of negative signals on the reputation of the top-tier supplier and the buyer.

Proposition 4b: The ability to safeguard their buyer's reputation through supplier-oriented CSR practices enhances the top-tier supplier's reputation in the business market.

In summary, the propositions are reflected in the modified theoretical framework on purchasingmarketing integration in the context of CSR depicted in Figure 2. This modified theoretical framework explains the CSR endeavors of top-tier suppliers in a competitive B2B supply chain context.

\section{Conclusion and implications}

In this study on corporate social responsibility (CSR) in B2B markets, we explored how top-tier suppliers effectively organize and market a supply chain-oriented CSR management capability. Furthermore, we studied how the attainable reputational effects for top-tier suppliers drive their behavior based on the assumptions of signaling theory. In particular, we investigated how top-tier suppliers assure upstream CSR standards and how they simultaneously market upstream practices as a service to their direct industrial customers. In order to develop theory, we modified an established model on purchasing-marketing integration. We adapted this framework to the context of CSR in business markets based on our research findings and the resulting propositions from investigating the CSRreputation link for the five best-practice case studies that form the basis of our research.

Moreover, we explored four distinct concepts for marketing superior CSR-related supply chain management capabilities in a B2B context: (1) Factbased communication of measurable CSR capabilities, (2) targeting of indirect customers and influencers, (3) marketing through education, and (4) marketing of CSR as a service. In terms of the marketing-reputation link we argue that the effec- tive marketing of CSR capabilities enhances a supplier's reputation if it sends consistent signals through the cross-functional integration of CSRrelated purchasing and marketing practices. Firms must foster the cross-functional integration between marketing and purchasing because it promotes signaling consistency. We identified that signaling consistency mediates the effect of upstream CSR capabilities on corporate reputation in the long run, especially as short-term incentives for the marketing function to greenwash prevail. On a more generic level, this study demonstrates that not only those companies with a popular brand name need to actively manage CSR in their business operations, but that suppliers in the upstream supply chain would also need to consider CSR in their business operations and among their own sub-suppliers. Moreover, the study demonstrates that suppliers too can benefit from being perceived as a CSR leader which of course sometimes entails significant cost but that in many cases, CSR awareness is considered simply an order qualifier and not an order winner.

\subsection{Managerial and theoretical contribution}

From a theoretical perspective, this paper contributes to cross-functional theory-building in the area of CSR by extending an established theoretical framework on marketing-purchasing integration in B2B markets to the context of CSR. Moreover, our paper is one of the first that considers the upstream assurance of CSR standards as a service to customers, which is especially the case in a B2B context. Moreover, we inductively derive four propositions on the correlation between the marketing of CSR and a supplier's reputation (see Figure 2), which can be a starting point for further theoretical or empirical endeavors.

For managers, our study provides decision support on investments in responsible upstream business practices and defines the factors that drive and limit the potential benefits of investments in such intangible assets. For instance, the identified business practices and distinct marketing concepts can serve as a starting point for defining individual concepts for using CSR-related capabilities, and may give practical guidance on how to manage crossfunctional integration in the context of CSR. Moreover, we assist practitioners in assessing the potential reputational effects of the investments in such CSR- 
related business practices in the long run. Furthermore, managers should be aware of the potential drawback related to negative effects and keep in mind that negative signals related to CSR by far outweigh the positive effects of actively marketing CSR-related capabilities. As in the context of supply chain-oriented CSR, consistent signaling is a necessary condition for long-term reputational benefit; firms must foster integration between marketing and purchasing because this fosters signaling consistency. However, managers need to be aware that the market drivers can change rapidly. Thus, the appropriate level of CSR practices upstream the chain and the corresponding level of purchasingmarketing integration must be adapted accordingly.

\subsection{Limitations and further research}

Our study has limitations that in turn should motivate further research. One such limitation is the sole focus on the top-tier supplier organization. Even though we conducted a rigorous multiple-case study with top-tier suppliers and used secondary data as a proxy for reputational effects, further research should seek to apply dyadic or even triadic research designs that involve sub-suppliers, customers, or other stakeholders such as NGOs, in order to externally validate our propositions. A further limitation of this study is the generalizability of our findings as our results could be specific to the composition of our sample. Thus, further research is needed to test whether the research propositions formulated in this study hold true in a sample with firms from different countries and industries, or for firms of different size and with a different geographic dispersion of their customer and supplier bases. Future research could test the viability of our formulated propositions in a large-scale empirical setting with data collected across industries, thereby contributing to further theoretical refinement. As a final suggestion for further research, scholars could evaluate how the marketing of supply chain-oriented CSR capabilities and the increased transparency of the supplier's business operations ultimately affects different dimensions of supply chain performance, such as buyer and supplier financial performance, supplier and buyer innovativeness, and supply chain efficiency or responsiveness.

\section{Appendices}

\section{Appendix I: Core questions of the semi- structured interview guide}

Questions related to interviewee:

1. How long have you been employed at your company and in which position(s)?

2. Are you currently involved with CSR issues at your company? How and since when?

CSR demands in the business market:

3. How would you describe your company's overall strategic approach towards CSR?

4. How would you describe your company's situation with regards to its position between buying firms and sub-suppliers in the context of CSR?

5. How would you describe the development of your buyer's demand for responsible business operations over time? What are the differences between different buyer groups?

6. What external and internal factors affect your company's engagement in responsible business operations? What are the buyer-driven factors?

Questions related to sales and marketing:

1. How would you describe the importance of a responsible brand image in your industry?

2. How is CSR integrated into your company's marketing operations?

3. How does your company market CSR-related internal business practices/initiatives?

4. How do you ensure that your buyers' CSRrelated demands are adequately reflected in your company's corporate image?

5. How do you communicate the attainment of social and environmental targets?

Questions related to purchasing and supply management:

1. How is your company's supply management function affected by your buyers' demands for responsible business operations? How does supply management react?

2. How is CSR incorporated into your supply management operations? 
3. How do CSR-related buyer demands affect your purchasing and supply management operations?

4. What does the CSR-related supplier evaluation process look like?

5. How does the compliance monitoring of your suppliers take place in practice?

Questions related to cross-functional collaboration:
1. Which function controls/steers your company's CSR initiatives?

2. How do the marketing and supply management functions collaborate in order to ensure that CSR-related buyer demands are implemented within your supply chain?

3. How do the marketing and supply management functions collaborate to market CSR to external parties such as customers or NGOs?

\section{Appendix II: Validity and reliability measures throughout the research design (Based on} Gibbert, Ruigrok, and Wicki 2008; Yin 2009)

\begin{tabular}{|c|c|c|c|c|}
\hline & Research phase & & & \\
\hline $\begin{array}{l}\text { Reliability/Validity } \\
\text { Criterion }\end{array}$ & Design & Case selection & Data gathering & Data analysis \\
\hline $\begin{array}{l}\text { Reliability } \\
\text { (demonstrates that the } \\
\text { operations of a study can be } \\
\text { repeated, with the same } \\
\text { results) }\end{array}$ & $\begin{array}{l}\text { Development of a } \\
\text { case study protocol } \\
\text { for primary and } \\
\text { secondary data }\end{array}$ & $\begin{array}{l}\text { Best-practice } \\
\text { sampling based on } \\
\text { multiple sampling } \\
\text { criteria }\end{array}$ & $\begin{array}{l}\text { - Shared question- } \\
\text { naire for all inter- } \\
\text { viewers } \\
\text { - Utilization of the } \\
\text { case study database }\end{array}$ & $\begin{array}{l}\text { - Involvement of a } \\
\text { third author who } \\
\text { did not gather the } \\
\text { data } \\
\text { - Coding and inter- } \\
\text { rater reliability as- } \\
\text { sessment }\end{array}$ \\
\hline $\begin{array}{l}\text { Internal validity } \\
\text { (establishes a causal rela- } \\
\text { tionship, whereby certain } \\
\text { conditions are shown to } \\
\text { lead to other conditions, as } \\
\text { distinguished by spurious } \\
\text { relationships) }\end{array}$ & $\begin{array}{l}\text { - Research grounded } \\
\text { in an established } \\
\text { framework of pur- } \\
\text { chasing-marketing } \\
\text { integration } \\
\text { - Interpretation of } \\
\text { results based on as- } \\
\text { sumptions of sig- } \\
\text { nalling theory }\end{array}$ & $\begin{array}{l}\text { - Sampling criteria } \\
\text { recorded in case } \\
\text { study protocol }\end{array}$ & $\begin{array}{l}\text { - Recording of alter- } \\
\text { native explanations } \\
\text { and developments } \\
\text { in the business en- } \\
\text { vironment of our } \\
\text { case companies }\end{array}$ & $\begin{array}{l}\text { - Pattern matching } \\
\text { - Triangulation of } \\
\text { multiple data } \\
\text { sources } \\
\text { - Logic models and } \\
\text { inductive reasoning } \\
\text { in conjunction with } \\
\text { signalling theory }\end{array}$ \\
\hline $\begin{array}{l}\text { Construct validity } \\
\text { (establishes correct opera- } \\
\text { tional measures for the } \\
\text { concepts being studied) }\end{array}$ & $\begin{array}{l}\text { Adoption of con- } \\
\text { structs from previ- } \\
\text { ous empirical works } \\
\text { in the field of sus- } \\
\text { tainability and risk } \\
\text { management }\end{array}$ & - N/A & $\begin{array}{l}\text { Collection of prima- } \\
\text { ry, archival and } \\
\text { publicly available } \\
\text { data as sources of } \\
\text { information } \\
\text { - Multiple interview- } \\
\text { ers }\end{array}$ & $\begin{array}{l}\text { - Key informants } \\
\text { reviewed our case } \\
\text { study protocol } \\
\text { eliminate mis- } \\
\text { understandings and } \\
\text { ambiguities } \\
\text { - Process tracing } \\
\text { based on a chain of } \\
\text { evidence }\end{array}$ \\
\hline $\begin{array}{l}\text { External validity } \\
\text { (establishes a domain in } \\
\text { which the study's findings } \\
\text { can be generalized) }\end{array}$ & $\begin{array}{l}\text { - Description of } \\
\text { sampling criteria to } \\
\text { the audience }\end{array}$ & $\begin{array}{l}\text { - Clear description of } \\
\text { case firms, context } \\
\text { and situation }\end{array}$ & $\begin{array}{l}\text { Use of results of } \\
\text { customer surveys, } \\
\text { industry reports, } \\
\text { NGO analyses and } \\
\text { business press arti- } \\
\text { cles as proxies for } \\
\text { effects corporate } \\
\text { reputation }\end{array}$ & - N/A \\
\hline
\end{tabular}




\section{Appendix III: Identified business practices previously mentioned in the literature}

\begin{tabular}{|c|c|c|c|c|c|c|c|}
\hline \multirow[t]{2}{*}{$\begin{array}{l}\text { Element in } \\
\text { Framework }\end{array}$} & \multirow[t]{2}{*}{ Business practice } & \multirow{2}{*}{$\begin{array}{l}\text { Explicitly } \\
\text { mentioned } \\
\text { in B2B con- } \\
\text { text }\end{array}$} & \multicolumn{5}{|c|}{$\begin{array}{l}\text { Practice ob- } \\
\text { served at firm }\end{array}$} \\
\hline & & & $\mathbf{A}$ & B & $\mathbf{C}$ & $\mathbf{D}$ & $\mathbf{E}$ \\
\hline \multirow{12}{*}{$\begin{array}{l}\text { Supplier- } \\
\text { oriented } \\
\text { CSR } \\
\text { practices }\end{array}$} & Selection/evaluation criteria cover TBL & YES & $\mathrm{Y}$ & $\mathrm{Y}$ & $\mathrm{Y}$ & $\mathrm{Y}$ & $\mathrm{Y}$ \\
\hline & Initial responsibility audits on 1st tier level & YES & Y & $\mathrm{Y}$ & $\mathrm{Y}$ & $\mathrm{Y}$ & $\mathrm{Y}$ \\
\hline & Written regulations for responsible purchasing & YES & $\mathrm{Y}$ & $\mathrm{Y}$ & $\mathrm{Y}$ & Y & $\mathrm{Y}$ \\
\hline & Vertical integration of value chain & YES & $\mathrm{N}$ & $\mathrm{Y}$ & $\mathrm{N}$ & $\mathrm{N}$ & $\mathrm{Y}$ \\
\hline & Suppliers need to confirm the firm's code of conduct & YES & $\mathrm{Y}$ & $\mathrm{Y}$ & $\mathrm{Y}$ & $\mathrm{Y}$ & $\mathrm{N}$ \\
\hline & Suppliers need to own CSR-related certifications & YES & $\mathrm{Y}$ & $\mathrm{Y}$ & $\mathrm{L}$ & $\mathrm{N}$ & $\mathrm{Y}$ \\
\hline & Regular responsibility audits on 1st tier level & YES & $\mathrm{Y}$ & $\mathrm{Y}$ & $\mathrm{Y}$ & $\mathrm{L}$ & $\mathrm{N}$ \\
\hline & Defined processes in case of supplier misconduct & YES & Y & $\mathrm{N}$ & $\mathrm{Y}$ & $\mathrm{N}$ & $\mathrm{N}$ \\
\hline & Development of suppliers towards CSR (e.g., certifications) & YES & Y & $\mathrm{Y}$ & $\mathrm{Y}$ & $\mathrm{N}$ & $\mathrm{Y}$ \\
\hline & Supplier risk management processes reflect CSR-related risks & NO & $\mathrm{N}$ & $\mathrm{N}$ & $\mathrm{Y}$ & $\mathrm{Y}$ & $\mathrm{N}$ \\
\hline & Measurement of the supply chain's carbon footprint & NO & $\mathrm{Y}$ & $\mathrm{Y}$ & $\mathrm{N}$ & $\mathrm{N}$ & $\mathrm{N}$ \\
\hline & Traceability concept for determining the origin of raw material & YES & $\mathrm{N}$ & $\mathrm{Y}$ & $\mathrm{N}$ & $\mathrm{N}$ & $\mathrm{Y}$ \\
\hline \multirow{8}{*}{$\begin{array}{l}\text { Customer- } \\
\text { oriented } \\
\text { CSR } \\
\text { practices }\end{array}$} & CSR information at top of corporate website & NO & $\mathrm{Y}$ & $\mathrm{Y}$ & $\mathrm{Y}$ & $\mathrm{Y}$ & $\mathrm{Y}$ \\
\hline & Promotion of CSR-related product features or product lines & NO & $\mathrm{Y}$ & $\mathrm{Y}$ & $\mathrm{L}$ & $\mathrm{Y}$ & $\mathrm{Y}$ \\
\hline & Target group-specific communication of CSR topics & NO & $\mathrm{Y}$ & $\mathrm{Y}$ & $\mathrm{Y}$ & $\mathrm{Y}$ & $\mathrm{Y}$ \\
\hline & Sustainability report covering the triple bottom line & YES & $\mathrm{Y}$ & $\mathrm{Y}$ & $\mathrm{Y}$ & $\mathrm{Y}$ & $\mathrm{N}$ \\
\hline & CSR communication strategy in place & NO & $\mathrm{Y}$ & $\mathrm{Y}$ & $\mathrm{Y}$ & $\mathrm{N}$ & $\mathrm{Y}$ \\
\hline & Active positioning as CSR innovator & YES & $\mathrm{Y}$ & $\mathrm{Y}$ & $\mathrm{N}$ & $\mathrm{N}$ & $\mathrm{Y}$ \\
\hline & CSR-related info material for external \& internal use & NO & $\mathrm{Y}$ & $\mathrm{Y}$ & $\mathrm{N}$ & $\mathrm{L}$ & $\mathrm{Y}$ \\
\hline & Joint CSR initiatives with NGOs driven by marketing & YES & $\mathrm{Y}$ & $\mathrm{Y}$ & $\mathrm{N}$ & $\mathrm{N}$ & $\mathrm{Y}$ \\
\hline \multirow{2}{*}{$\begin{array}{l}\text { Marketing- } \\
\text { Purchasing } \\
\text { integration }\end{array}$} & Centrally available written regulations related to CSR & YES & $\mathrm{Y}$ & $\mathrm{Y}$ & $\mathrm{Y}$ & $\mathrm{Y}$ & $\mathrm{Y}$ \\
\hline & Education of workforce in CSR-related topics & $\mathrm{NO}$ & $\mathrm{Y}$ & $\mathrm{Y}$ & $\mathrm{Y}$ & $\mathrm{L}$ & $\mathrm{Y}$ \\
\hline
\end{tabular}

$Y '=$ Yes, the top-tier supplier engages in the CSR practice in significant amounts

' $N$ ' $=$ No, the top-tier supplier does not engage in the CSR practice

' $L$ ' $=$ The company shows limited engagement in the identified CSR practice 


\section{References}

Adams, Marjorie E., George S. Day, and Deborah Dougherty (1998): Enhancing New Product Development Performance: An Organizational Learning Perspective, Journal of Product Innovation Management, 15 (5): 403-422.

Aitken, James, Paul Childerhouse, and Denis R. Towill (2003): The Impact of Product Life Cycle on Supply Chain Strategy. International Journal of Production Economics, 85 (2): 127-40.

Amaeshi, Kenneth M., Onyeka K. Osuji, and Paul Nnodim (2008): Corporate Social Responsibility in Supply Chains of Global Brands: A Boundaryless Responsibility? Clarifications, Exceptions and Implications, Journal of Business Ethics, 81 (1): 223-234.

Auger, Pat, Timothy M. Devinney, Jordan J. Louviere, and Paul F. Burke (2010): The Importance of Social Product Attributes in Consumer Purchasing Decisions: A Multi-Country Comparative Study, International Business Review, 19 (2): 140-159.

Balmer, John M. T. and Stephen A. Greyser (2006): Corporate Marketing: Integrating Corporate Identity, Corporate Branding, Corporate Communications, Corporate Image and Corporate Reputation, European Journal of Marketing, 40 (7/8): 730-741.

Bone, Paula F. and Robert J. Corey (2000): Packaging Ethics: Perceptual Differences among Packaging Professionals, Brand Managers and Ethically Interested Consumers, Journal of Business Ethics, 24 (3): 199-213.

Boyer, Ken K. and Morgan L. Swink (2008): Empirical Elephants: Why Multiple Methods are Essential to Quality Research in Operations and Supply Chain Management, Journal of Operations Management, 26 (3): 338-344.

Brickson, Shelley L. (2007): Organizational Identity Orientation: The Genesis of the Role of the Firm and Distinct Forms of Social Value, Academy of Management Review, 32 (3): 864-888.

Campbell, John L. (2007): Why Would Corporations Behave in Socially Responsible Ways? An Institutional Theory of Corporate Social Responsibility, Academy of Management Review, 32 (3): 946-967.

Carrington, Michal J., Benjamin A. Neville, and Gregory J. Whitwell (2010): Why Ethical Consumers Don't Walk Their Talk: Towards a Framework for Understanding the Gap Between the Ethical Purchase Intentions and Actual Buying Behavior of Ethically Minded Consumers, Journal of Business Ethics, 97 (1): 139158.

Carroll, Archie B. (1999): Corporate Social Responsibility: Evolution of a Definitional Construct, Business \& Society, 38 (3): 268295.

Carter, Craig R. and P. Liane Easton (2011): Sustainable Supply Chain Management: Evolution and Future Directions, International Journal of Physical Distribution and Logistics Management, 41 (1): 46-62.

Carter, Craig R. and Marianne M. Jennings (2004): The Role of Purchasing in Corporate Social Responsibility: A Structural Equation Analysis, Journal of Business Logistics, 25 (1): 145-186.

Carter Craig R. and Dale S. Rogers (2008): A Framework of Sustainable Supply Chain Management: Moving Toward New Theory, International Journal of Physical Distribution and Logistics Management, 38 (5): 360-387.
Childerhouse, Paul, James Aitken, and Denis R. Towill (2002): Analysis and Design of Focused Demand Chains, Journal of Operations Management, 20 (6): 675-689.

Closs, David J., Cheri Speier, and Nathan Meacham (2011): Sustainability to Support End-To-End Value Chains: The Role of Supply Chain Management, Journal of the Academy of Marketing Science, 39 (1): 101-116.

Connelly, Brian L., David J. Ketchen, and Stanley F. Slater (2011): Toward a 'Theoretical Toolbox' for Sustainability Research in Marketing, Journal of the Academy of Marketing Science, 39 (1): 86-100.

Cornelissen, Joep P., S. Alexander Haslam, and John M. T. Balmer (2007): Social Identity, Organizational Identity and Corporate Identity: Towards an Integrated Understanding of Processes, Patternings, and Products, British Journal of Management, 18 (S1): 1-16.

Crane, Andrew (1999): Are you Ethical? Please Tick Yes or No: On Researching Ethics in Business Organizations, Journal of Business Ethics, 20 (3): 237-248.

Day, George S. (1994): The Capabilities of Market-Driven Organizations, Journal of Marketing, 58 (4): 37-52.

Eberl, Markus and Manfred Schwaiger (2005): Corporate Reputation: Disentangling the Effects on Financial Performance, European Journal of Marketing, 39 (7/8): 838-854.

Eisenhardt, Kathleen M. (1989): Building Theories from Case Study Research, Academy of Management Review, 14 (4): 532550 .

Eisenhardt, Kathleen M. and Melissa E. Graebner (2007): Theory Building from Cases: Opportunities and Challenges, Academy of Management Journal, 50 (1): 25-32.

Elkington, John (1998): Cannibals with Forks: The Triple Bottom Line of 21st Century Business, New Society Pbublishers: Stony Creek, CT.

FAZ, Frankfurter Allgemeine Zeitung (2012): Verseuchte Erdbeeren lösten Brechdurchfall aus, http://www.faz.net/aktuell/gesell schaft/gesundheit/norovirus-erkrankungen-verseuchte-erdbeere n-loesten-brechdurchfall-aus-11919056.html (Access date: 201210-19).

Foley, Anthony and John Fahy (2004): Towards a Further Understanding of the Development of Market Orientation in the Firm: A Conceptual Framework Based on the Market-Sensing Capability, Journal of Strategic Marketing, 12 (4): 219-230.

Gadde, Lars E. and Hakan Hakansson (2001): Supply Network Strategies, Wiley: Chichester, UK.

Ganesan, Shankar (1994): Determinants of Long-Term Orientation in Buyer-Seller Relationships, Journal of Marketing, 58 (2): 1-19.

Gerring, John (2006): Case Study Research: Principles and Practices, Cambridge University Press: Cambridge, UK.

Gibbert, Michael, Winfried Ruigrok, and Barbara Wicki (2008): What Passes as a Rigorous Case Study?, Strategic Management Journal, 29 (13): 1465-1474.

Hansen, Havard, Bendik M. Samuelsen, and Pal R. Silseth (2008): Customer Perceived Value in B-t-B Service Relationships: Investigating the Importance of Corporate Reputation, Industrial Marketing Management, 37 (2): 206-217. 
Harrison, Jeffrey S. and R. Edward Freeman (1999): Stakeholders, Social Responsibility, and Performance: Empirical Evidence and Theoretical Perspectives, Academy of Management Journal, 42 (5): $479-485$.

Hart, Stuart L. (1995): A Natural Resource-Based View of Strategy, Academy of Management Review, 20 (4): 986-1014.

Henriques, Adrian and Julie Richardson (2004): The Triple Bottom Line: Does it all Add Up?, Earthscan: London, UK

Hill, Terry (1985): Manufacturing Strategy: The Strategic Management of the Manufacturing Function, Macmillan: Basingstoke, UK.

Hollos, Daniel, Constantin Blome, and Kai Foerstl (2012): Does Sustainable Supplier Co-Operation Affect Performance? Examining Implications for the Triple Bottom Line, International Journal of Production Research, 50 (11): 2968-2986.

Howard, Jennifer, Jennifer Nash, and John Ehrenfeld (1999): Industry Codes as Agents of Change: Responsible CARE Adoption by US Chemical Companies, Business Strategy and the Environment, 8 (5): 281-295.

Hult, G. Tomas M. (2011): Market-Focused Sustainability: Market Orientation Plus!, Journal of the Academy of Marketing Science, 39 (1): 1-6.

Hunt, Shelby D. (2011): Sustainable Marketing, Equity, and Economic Growth: A Resource-Advantage, Economic Freedom Approach, Journal of the Academy of Marketing Science, 39 (1): 7-20.

Husted, Bryan W. and José De Jesus Salazar (2006): Taking Friedman Seriously: Maximizing Profits and Social Performance, Journal of Management Studies, 43 (1): 75-91.

Janney, Jay J. and Steve Gove (2011): Reputation and Corporate Social Responsibility Aberrations, Trends, and Hypocrisy: Reactions to Firm Choices in the Stock Option Backdating Scandal, Journal of Management Studies, 48 (7): 1562-1585.

Jones, Peter, Collin Clarke-Hill, Daphne Comfort, and David Hillier (2008): Marketing and Sustainability, Marketing Intelligence and Planning, 26 (2): 123-130.

Kamath, Rajan R. and Jeffrey K. Liker (1994): A Second Look at Japanese Product Development, Harvard Business Review, 72 (6): 154-170.

Kourula, Arno (2010): Corporate Engagement with NonGovernmental Organizations in Different Institutional Contexts: A Case Study of a Forest Products Company, Journal of World Business, 45 (4): 395-404.

Krause, Daniel R., Stephan Vachon, and Robert D. Klassen (2009): Special Topic Forum on Sustainable Supply Chain Management: Introduction and Reflections on the Role of Purchasing Management, Journal of Supply Chain Management, 45 (4): 1825 .

Lambert, Douglas M. and Sebastián J. García-Dastugue (2006): Cross-Functional Processes for the Implementation of ServiceDominant Logic, in: Robert F. Lusch and Stephen L. Vargo (eds.): The Service-Dominant Logic of Marketing: Dialog, Debate and Directions, Sharpe: Armonk, NY, 150-165.

Lee, Hau L., Mitchell M. Tseng, and David Hoyt (2008): Unsafe for children: Mattel's toy recalls and supply chain management, http://homes.ieu.edu.tr/ mdemirbag/mattel.pdf (Access date: 2013-06-10).
Lee, Su-Yol and Robert D. Klassen (2008): Drivers and Enablers that Foster Environmental Management Capabilities in Smalland Medium-Sized Suppliers in Supply Chains, Production and Operations Management, 17 (6): 573-586.

Leppelt, Thomas, Kai Foerstl, Carsten Reuter, and Evi Hartmann (2011): Sustainability Management beyond Organizational Boundaries: Sustainable Supplier Relationship Management in the Chemical Industry, http://dx.doi.org/10.1016/j.jclepro.2011. 10.011 (Access date: 2013-06-10).

Lockett, Andy, Jeremy Moon, and Wayne Visser (2006): Corporate Social Responsibility in Management Research: Focus, Nature, Salience and Sources of Influence, Journal of Management Studies, 43 (1): 115-136.

Luchs, Michael G., Rebecca W. Naylor, Julie R. Irwin, and Rajagopal Raghunathan (2010): The Sustainability Liability: Potential Negative Effects of Ethicality on Product Preference, Journal of Marketing, 74 (5): 18-31.

Lusch, Robert F. (2011): Reframing Supply Chain Management: A Service-Dominant Logic Perspective, Journal of Supply Chain Management, 47 (1): 14-18.

McWilliams, Abagail and Donald S. Siegel (2001): Corporate Social Responsibility: A Theory of the Firm Perspective, Academy of Management Review, 26 (1): 117-127.

McWilliams, Abagail, Donald S. Siegel, and Patrick M. Wright (2006): Corporate Social Responsibility: Strategic Implications, Journal of Management Studies, 43 (1): 1-18.

Miles, Matthew B. and A. Michael Huberman (1994): Qualitative Data Analysis: An Expanded Sourcebook Sage: Thousand Oaks, CA.

Monczka, Robert M., Robert J. Trent, and Robert B. Handfield (2005): Purchasing and Supply Chain Management, $3^{\text {rd }}$ ed., Thomson: Mason, $\mathrm{OH}$.

Mudambi, Susan (2002): Branding Importance in Business-toBusiness Markets: Three Buyer Clusters, Industrial Marketing Management, 31 (6): 525-533.

Ndofor, Hermann A. and Edward Levitas (2004): Signaling the Strategic Value of Knowledge, Journal of Management, 30 (5): 685-702.

Pagell, Mark (2004): Understanding the Factors that Enable and Inhibit the Integration of Operations, Purchasing and Logistics, Journal of Operations Management, 22 (5): 459-487.

Pagell, Mark and Zhaohui Wu (2009): Building a More Complete Theory of Sustainable Supply Chain Management Using Case Studies of 10 Exemplars, Journal of Supply Chain Management, 45 (2): 37-56.

Patton, Michael Q. (1990): Qualitative Evaluation and Research Methods, $2^{\text {nd }}$ ed., Sage: Newbury Park, CA.

Paulraj, Antony (2011): Understanding the Relationships between Internal Resources and Capabilities, Sustainable Supply Management and Organizational Sustainability, Journal of Supply Chain Management, 47 (1): 19-37.

Perry, Chad (1998): Processes of a Case Study Methodology for Postgraduate Research in Marketing, European Journal of Marketing, 32 (9/10): 785-802.

Rao, Hayagreeva (1994): The Social Construction of Reputation: Certification Contests, Legitimation, and the Survival of Organiza- 
tions in the American Automobile Industry 1895-1912, Strategic Management Journal, 15 (S1): 29-44.

Rindova, Violina P., Ian O. Williamson, Antoaneta P. Petkova, and Joy M. Sever (2005): Being Good or Being Known: An Empirical Examination of the Dimensions, Antecedents, and Consequences of Organizational Reputation, Academy of Management Journal, 48 (6): 1033-1049.

Schoenherr, Tobias, Sachin B. Modi, W. C. Benton, Craig R. Carter, Thomas Y. Choi, Paul D. Larson, Michiel R. Leenders, Vincent A. Mabert, Ram Narasimhan, and Stephan M. Wagner (2012): Research Opportunities in Purchasing and Supply Management, International Journal of Production Research, 50 (16): 4556-4579.

Schueth, Steve (2003): Socially Responsible Investing in the United States, Journal of Business Ethics, 43 (3): 189-194.

Seuring, Stefan, and Martin Mueller (2008): From a Literature Review to a Conceptual Framework for Sustainable Supply Chain Management, Journal of Cleaner Production, 16 (15): 1699-1710.

Sheth, Jagdish N., Arun Sharma, and Gopalkrishnan R. Iyer (2009): Why Integrating Purchasing with Marketing is Both Inevitable and Beneficial, Industrial Marketing Management, 38 (8): 865-871.

Shrivastava, Paul (1995): The Role of Corporations in Achieving Ecological Sustainability, Academy of Management Review, 20 (4): 936-960.

Smirnova, Maria, Stephan C. Henneberg, Bahar Ashnai, Peter Naudé, and Stefanos Mouzas (2011): Understanding the Role of Marketing-Purchasing Collaboration in Industrial Markets: The Case of Russia, Industrial Marketing Management, 40 (1): 54-64.

Smith, Ted, David A. Sonnenfeld, and David Pellow (2006): Challenging the Chip: Labor Rights and Environmental Justice in the Global Electronics Industry, Temple University Press: Philadelphia, PA.

Spence, Laura and Michael Bourlakis (2009): The Evolution from Corporate Social Responsibility to Supply Chain Responsibility: The Case of Waitrose, Supply Chain Management: An International Journal, 14 (4): 291-302.

Srivastava, Rajendra K., Tasadduq A. Shervani, and Liam Fahey (1999): Marketing, Business Processes, and Shareholder Value: An Organizationally Embedded View of Marketing Activities and the Discipline of Marketing, Journal of Marketing, 63 (Special Issue): 168-179.

Strauss, Anselm and Juliet M. Corbin (1998): Basics of Qualitative Research: Grounded Theory Procedures and Techniques, $2^{\text {nd }}$ ed., Sage: Thousand Oaks, CA.

Tang, Christopher S. (2008): Making Products Safe: Process and Challenges, International Commerce Review, 8 (1): 48-55.

Tate, Wendy L., Lisa M. Ellram, and Jon F. Kirchoff (2010): Corporate Social Responsibility Reports: A Thematic Analysis Related to Supply Chain Management, Journal of Supply Chain Management, 46 (1): 19-44.

Van Tulder, Rob and Alex van der Zwart (2006): International Business-Society Management: Linking Corporate Responsibility and Globalization, Routledge: London, UK.
Wagner, Stephan M., Linda S. Coley, and Eckhard Lindemann (2011): Effect of Suppliers' Reputation on the Future of BuyerSupplier Relationships: The Mediating Roles of Outcome Fairness and Trust, Journal of Supply Chain Management, 47 (2): 29-48.

Williams, Alvin J., Larry C. Giunipero, and Tony L. Henthorne (1994): The Cross-Functional Imperative: The Case of Marketing and Purchasing, International Journal of Purchasing and Materials Management, 30 (2): 28-33.

Wilson, Elizabeth J. and Richard P. Vlosky (1997): Partnering Relationship Activities: Building Theory from Case Study Research, Journal of Business Research, 39 (1): 59-70.

Wolf, Julia (2011): Sustainable Supply Chain Management Integration: A Qualitative Analysis of the German Manufacturing Industry, Journal of Business Ethics, 102 (2): 221-235.

Wu, Zhaohui and Thomas Y. Choi (2005): Supplier-Supplier Relationships in the Buyer-Supplier Triad: Building Theories from Eight Case Studies, Journal of Operations Management, 24 (1): 27-52.

Wynstra, Finn, Fredrik von Corswant, and Martin Wetzels (2010): In Chains? An Empirical Study of Antecedents of Supplier Product Development Activity in the Automotive Industry, Journal of Production and Innovation Management, 27 (5): 625-639.

Yin, Robert K. (2009): Case Study Research: Design and Methods, $4^{\text {th }}$ ed., Sage: Thousand Oaks, CA.

\section{Biographies}

Thomas Leppelt is doctoral student at the Chair of Supply Chain Management at Friedrich-Alexander University, ErlangenNuremberg (Germany). His primary areas of research include supplier-buyer relationships, sustainability, and strategic supply chain management. He has presented his research at the IPSERA conference and has been awarded with a scholarship by IPSERA. He has been published in the Journal of Cleaner Production.

Kai Foerstl is assistant professor for global sourcing at EBS University of Business and Law in Wiesbaden, Germany. Over the last few years he has been involved in industrial research projects in the pharmaceutical, automotive, and logistics services industries. His primary areas of research include global sourcing decision making, upstream innovation adoption, and sustainable supply chain management. He has had his research published in the Journal of Supply Chain Management, Journal of Purchasing and Supply Management, International Journal of Production Research, International Journal of Operations and Production Management, Supply Chain Management Review, and other managerial outlets. He received the Harold E. Fearon Best Paper Award 2010 of the Journal of Supply Chain Management.

Evi Hartmann is Professor for Supply Chain Management at Friedrich-Alexander University, Erlangen-Nuremberg (Germany). Her primary areas of research interest include services supply management, global sourcing, and environmental supply chain management. She has been published in the Journal of Supply Chain Management, Journal of International Management, Industrial Marketing Management, International Journal of Production Economics, Journal of World Business, and other managerial and academic outlets. 